\title{
Observations of elevated formaldehyde over a forest canopy suggest missing sources from rapid oxidation of arboreal hydrocarbons
}

\author{
W. Choi ${ }^{1}$, I. C. Faloona ${ }^{1}$, N. C. Bouvier-Brown ${ }^{2, *}$, M. McKay ${ }^{2, * *}$, A. H. Goldstein ${ }^{2}$, J. Mao ${ }^{3, * * *}$, W. H. Brune ${ }^{3}$, \\ B. W. LaFranchi ${ }^{4, * * *}$, R. C. Cohen ${ }^{4,5}$, G. M. Wolfe ${ }^{6}$, J. A. Thornton ${ }^{7}$, D. M. Sonnenfroh ${ }^{8}$, and D. B. Millet ${ }^{9}$ \\ ${ }^{1}$ University of California, Davis, Dept. of Land, Air, and Water Resources, Davis, California, USA \\ ${ }^{2}$ University of California, Berkeley, Dept. of Environmental Science, Policy \& Management, Berkeley, California, USA \\ ${ }^{3}$ Pennsylvania State University, Dept. of Meteorology, University Park, Pennsylvania, USA \\ ${ }^{4}$ University of California, Berkeley, Dept. of Chemistry, Berkeley, California, USA \\ ${ }^{5}$ University of California, Berkeley, Dept. of Earth and Planetary Science, Berkeley, California, USA \\ ${ }^{6}$ University of Washington, Dept. of Chemistry, Seattle, Washington, USA \\ ${ }^{7}$ University of Washington, Dept. of Atmospheric Sciences, Seattle, Washington, USA \\ ${ }^{8}$ Physical Sciences Inc., Atmospheric Sciences group, Andover, Massachusetts, USA \\ ${ }^{9}$ University of Minnesota, Dept. of Soil, Water, and Climate, St. Paul, Minnesota, USA \\ * now at: Loyola Marymount University, Dept. of Chemistry and Biochemistry, Los Angeles, California, USA \\ ***now at: California Air Resources Board, Sacramento, California, USA \\ **** now at: Harvard University, School of Engineering and Applied Sciences, Cambridge, Massachustte, USA \\ ***** now at: Lawrence Livermore National Lab, Center for Accelerator Mass Spectrometry, Livermore, California, USA
}

Received: 23 March 2010 - Published in Atmos. Chem. Phys. Discuss.: 16 April 2010

Revised: 5 August 2010 - Accepted: 1 September 2010 - Published: 17 September 2010

\begin{abstract}
To better understand the processing of biogenic VOCs (BVOCs) in the pine forests of the US Sierra Nevada, we measured $\mathrm{HCHO}$ at Blodgett Research Station using Quantum Cascade Laser Spectroscopy (QCLS) during the Biosphere Effects on Aerosols and Photochemistry Experiment (BEARPEX) of late summer 2007. Four days of the experiment exhibited particularly copious $\mathrm{HCHO}$, with midday peaks between 15-20 ppbv, while the other days developed delayed maxima between $8-14 \mathrm{ppbv}$ in the early evening. From the expansive photochemical data set, we attempt to explain the observed HCHO concentrations by quantifying the various known photochemical production and loss terms in its chemical budget. Overall, known chemistry predicts a factor of 3-5 times less $\mathrm{HCHO}$ than observed. By examining diurnal patterns of the various budget terms we conclude that, during the high HCHO period, local, highly reactive oxidation chemistry produces an abundance of formaldehyde at the site. The results support the hypothesis of previous work at Blodgett Forest suggesting that large quantities of oxidation products, observed directly above the ponderosa pine canopy,
\end{abstract}

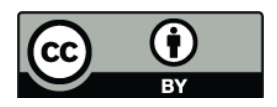

Correspondence to: W. Choi (wschoi@ucdavis.edu) are evidence of profuse emissions of very reactive volatile organic compounds (VR-VOCs) from the forest. However, on the majority of days, under generally cooler and more moist conditions, lower levels of HCHO develop primarily influenced by the influx of precursors transported into the region along with the Sacramento plume.

\section{Introduction}

Formaldehyde (HCHO) is one of the most abundant volatile organic compounds (VOCs) found in the atmosphere. It is emitted directly from human activities, such as vehicular exhaust, wood burning, and industrial activity, but is formed in greatest abundance from the oxidation of other VOCs (Facchini et al., 1992; Lee et al., 1998; Seinfeld and Pandis, 1998). Not only does HCHO play an important role in tropospheric photochemistry as both a source and a sink of free radicals (Grosjean, 1982), and as an important precursor of molecular hydrogen (Hauglustaine and Ehhalt, 2002), but it is also believed to be a highly toxic air pollutant (Suh et al., 2000). Tan et al. (2001) showed HCHO to be a significant source of $\mathrm{HO}_{\mathrm{x}}\left(=\mathrm{OH}+\mathrm{HO}_{2}\right)$ in a mixed forest in Northern Michigan, and thus it is often strongly linked to the formation

Published by Copernicus Publications on behalf of the European Geosciences Union. 
of tropospheric ozone. Bowman et al. (1995) calculated ozone productivities for carbonyls, aromatics, alkanes, and alkenes for the Southern California Air Quality Study air pollution episode of August 1987, concluding that HCHO is one of the most effective ozone producing VOCs as well as the greatest $\mathrm{OH}$ precursor in that case. In forest environments, most $\mathrm{HCHO}$ is produced from photooxidation of biogenic VOCs (BVOC) rather than from direct emissions (Lee et al., 1998). Virtually all oxidation of hydrocarbons in the atmosphere involves the production of $\mathrm{HCHO}$ at some point in its reaction sequence. Sumner et al. (2001) reported that isoprene was the most important precursor of HCHO in the same deciduous/coniferous forest as the Tan et al. (2001) study, contributing $82 \%$ on average to the calculated midday HCHO production rate. However, little is known about the effect of biogenic VOCs on regional photochemistry in coniferous forests where 2-methyl-3-buten-2-ol (MBO) and monoterpenes, rather than isoprene, are predominant. Further complicating the picture, Holzinger et al. (2005) observed large quantities of putative oxidation products near the canopy top at Blodgett Forest, implicating a source of unidentified, very-reactive BVOCs comparable in magnitude to the source of MBO. Emissions of such VOCs might be responsible for the reactive (chemical) component of the canopy ozone flux observed by Kurpius and Goldstein (2003) and would be expected to leave a large $\mathrm{HCHO}$ signature in the near canopy environment.

High concentrations of $\mathrm{HCHO}$ in the polluted boundary layer have been documented in a number of previous studies: 19 ppbv by Grosjean et al. (1990) in Sao Paulo to 25 ppbv by Possanzini et al. (1996) in Rome. The largest values tend to be found in urban centers where primary emissions undoubtedly hold sway. In forested and semi-rural regions peak concentrations are typically lower, e.g. between 4.5 (Macdonald et al., 2001) and 12 ppbv (Sumner et al., 2001). However, Largiuni et al. (2002) have reported concentrations up to $17 \mathrm{ppbv}$ in a botanical garden in Florence, Italy and Müller et al. (2002) observed $18 \mathrm{ppbv}$ over a blooming field of rape in Germany, possibly indicating that in certain locales where anthropogenic emissions are blended with biogenic VOCs high levels of formaldehyde may be generated. Here we report $\mathrm{HCHO}$ concentrations which peak between 8-20 ppb over a rural pine plantation $\sim 75 \mathrm{~km}$ downwind of the California state capital during the summer/fall transition. Our focus is on using these observations and a unique suite of simultaneous supporting photochemical and meteorological observations to test the current understanding of $\mathrm{HCHO}$ sources.

Local atmospheric HCHO concentrations are controlled by advection, direct emissions from point and regional sources, secondary chemical production from various precursors such as biogenic and anthropogenic VOCs, $\mathrm{CH}_{4}$, and PAN, in conjunction with loss mechanisms, including the reaction with $\mathrm{OH}$, photolysis, and dry deposition. In a fairly remote forest environment, direct emissions are likely to be insignificant, and hence the governing equation of mean boundary layer [HCHO] can be expressed as Eq. (1), where $U$ is the mean wind speed (in the $\mathrm{x}$-direction aligned with the mean wind), $k_{\mathrm{OH}}$ and $j_{\mathrm{HCHO}}$ are rate constants for the $\mathrm{OH}+\mathrm{HCHO}$ reaction and photolysis of $\mathrm{HCHO}$, respectively, $V_{\mathrm{d}}$ is dry deposition velocity, and $H$ is the boundary layer mixing height.

$$
\begin{aligned}
& \frac{\partial[\mathrm{HCHO}]}{\partial t}=-U \times \frac{\partial[\mathrm{HCHO}]}{\partial x}+P_{\mathrm{HCHO}} \\
& -\left(k_{\mathrm{OH}}[\mathrm{OH}]+j_{\mathrm{HCHO}}+\frac{V_{\mathrm{d}}}{H}\right) \times[\mathrm{HCHO}]
\end{aligned}
$$

$P_{\mathrm{HCHO}}$ represents a total production term from atmospheric photochemical processes, including biogenic VOCs $+\mathrm{OH}$ and $\mathrm{O}_{3}$ reactions, and methyl peroxy $\left(\mathrm{CH}_{3} \mathrm{O}_{2}\right)$ radical formation from $\mathrm{CH}_{4}$ oxidation and peroxyacetyl (PA, $\left.\mathrm{CH}_{3} \mathrm{C}(\mathrm{O}) \mathrm{O}_{2}\right)$ radicals. We neglect solubility-driven partitioning of $\mathrm{HCHO}$ into particulate matter, which is likely to be minor (Munger et al., 1984).

\section{The Experiment (BEARPEX 2007)}

\subsection{Site description}

Measurements were conducted near the Blodgett Forest Research Station located on the western slope of the Sierra Nevada Mountains in California $\left(38.9^{\circ} \mathrm{N}, 120.6^{\circ} \mathrm{W} ; 1315 \mathrm{~m}\right.$ elevation) approximately $75 \mathrm{~km}$ northeast of Sacramento. The managed forest consists mainly of conifer trees (30\% of ground area), dominated by Pinus ponderosa L. with individuals of Douglas fir, white fir, and incense-cedar, a few oak trees (California black oak; $2 \%$ ), forbs (7\%) and shrubs (Manzanita and Ceanothus; 25\%) (Goldstein et al., 2000; Misson et al., 2005). The mean canopy height during the experiment in late summer 2007 was $7.9 \mathrm{~m}$. The summertime meteorology at the site is characterised by a strong, thermally driven cross-valley circulation with anabatic (westsouthwesterly, upslope) winds bringing a complex mixture of anthropogenic and biogenic compounds to the site throughout the day followed by katabatic flow (east-northeasterly, downslope) of relatively cleaner air overnight. The major anthropogenic emission source is vehicular traffic in the Sacramento region and there are no major industrial point sources between Sacramento and Blodgett Forest (Dillon et al., 2002). The characteristics of the Sacramento plume during the daytime are described in detail by Dillon et al. (2002) and Murphy et al. (2007). Between Sacramento and Blodgett Forest, an oak forest is situated with a width of approximately $30 \mathrm{~km}$ transverse to the predominant wind direction (Goldstein et al., 2000), and is a large source of isoprene to the plume.

Two observation towers were in place at the site; a $15 \mathrm{~m}$ walk-up tower (south tower) and a $18 \mathrm{~m}$ scaffolding tower, $10 \mathrm{~m}$ to the north. The HCHO sample inlet (1/4" OD Teflon tubing) was installed near the top of the south tower $(11.8 \mathrm{~m})$, 
drawing the ambient air sample into a trailer at the base at a flow rate of 2.4 LPM. Power was supplied by a propane generator located $\sim 125 \mathrm{~m}$ north of the measuring towers, perpendicular to the prevailing wind directions.

\subsection{QCL spectroscopy of HCHO}

Atmospheric formaldehyde was measured with a thermoelectrically-cooled distributed feedback quantum cascade laser spectrometer, designed and developed by Physical Science Inc. A multi-pass Herriott cell (operated at 50 to $70 \mathrm{mbar}$ ) is used to obtain high sensitivity. The spectrometer uses two liquid nitrogen cooled, photovoltaic $\mathrm{HgCdTe}$ detectors ( $6 \mu \mathrm{m}$ cutoff, Fermionics) in a Balanced Ratiometric Detection (BRD) technique that electronically cancels common mode laser noise (Hobbs, 1997). Approximately $35 \%$ of the QCL beam is diverted by a $2 \mu \mathrm{m}$ thick pellicle beam-splitter to the reference detector before the transmitted beam is sent on through a Herriott cell with an effective pathlength of $100 \mathrm{~m}$ through the absorbing gas sample.

The laser was originally fabricated to emit near $5.7 \mu \mathrm{m}$, which is the $\nu_{2}$ band of $\mathrm{HCHO}(\mathrm{C}=\mathrm{O}$ stretch mode: $1746 \mathrm{~cm}^{-1}$ Perrin et al., 2003). However, the active lasing surface used in this experiment emitted closer to $1721 \mathrm{~cm}^{-1}$, and the thermoelectric cooling system was not able to cool the laser mount below $-10^{\circ} \mathrm{C}$ at typical ambient room temperature, limiting the tuning range to $\sim 2 \mathrm{~cm}^{-1}$. Controlling the laser mount temperature $\left(-10.5^{\circ} \mathrm{C}\right.$ to $\left.8.0^{\circ} \mathrm{C}\right)$, the emission line was scanned in the range from 1720.0 to $1722.2 \mathrm{~cm}^{-1}$, with a standard gas from a NIST traceable permeation tube to determine the optimal target wavenumber to measure the HCHO absorption feature. Using the published FTIR spectra of the $\nu_{2}$ absorption band of HCHO (Gratien et al., 2007), and the corresponding spectral features observed during the scan, we concluded that the optimal wavelength for routine detection was $1721 \mathrm{~cm}^{-1}$ in a P-branch band of the rovibrational spectrum (Fig. 1).

\subsubsection{Spectroscopic interferences}

Water vapor is one of the most potentially important interferences in any spectroscopic measurement of atmospheric $\mathrm{HCHO}$. In order to experimentally verify whether water vapor has any interfering absorption at $1721 \mathrm{~cm}^{-1}$, we installed a humidifier into the zero air stream, diluting the output of the $\mathrm{HCHO}$ permeation system. In addition, to avoid the effect of any changes in the background spectrum for humidified and dry samples, zero air alternately flowed through and then bypassed the humidifier before adding HCHO gas from the permeation tube. The difference in absorbance obtained from humid and dry samples was $<0.1 \%$, indicating that the interference of water vapor absorption is negligible at $1721 \mathrm{~cm}^{-1}$.

Although formic acid is known to be sufficiently active near the $v_{2}$ band of $\mathrm{HCHO}\left(1746 \mathrm{~cm}^{-1}\right)$ due to its $\mathrm{C}=\mathrm{O}$

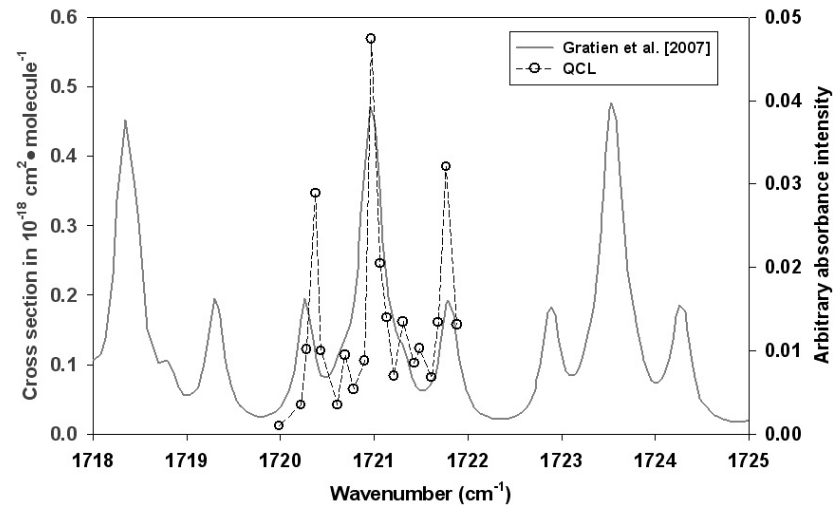

Fig. 1. Peak absorption strength of $\mathrm{HCHO}$ as a function of wavenumber $\left(\mathrm{cm}^{-1}\right)$ used to determine the target for ambient $\mathrm{HCHO}$ detection. Left y-axis is $v_{2}$ absorption cross section $\left(\times 10^{-18} \mathrm{~cm}^{2}\right.$ molecule ${ }^{-1}$; gray line $)$ measured by Gratien et al. (2007) and the right y-axis is an arbitrary absorbance (open circle and dashed line) obtained from experiments with the quantum cascade laser (QCL) spectrometer. HCHO of about $11.8 \mathrm{ppm}$ from a permeation system was used in the multipass cell at 60 mbar.

double bond, the strongest absorption band is located at $1765 \mathrm{~cm}^{-1}$ which is far from our target wavenumber. The only possible interference from formic acid in $\mathrm{HCHO}$ absorption around $1721 \mathrm{~cm}^{-1}$ is the $\mathrm{C}=\mathrm{O}$ stretch mode for cisDCOOH (Macoas et al., 2003). However, considering the ratio of cis- $\mathrm{HCOOH}$ to trans-HCOOH is $\sim 10^{-3}$ at $298 \mathrm{~K}$, and further considering it is deuterated, which is only a very minor constituent in the atmosphere $(0.015 \%$ abundance in the ocean), it is unlikely that there is any significant interference from deuterated formic acid at $1721 \mathrm{~cm}^{-1}$. Another possible interference may come from acetaldehyde. Acetaldehyde has a strong absorption band $\left(v_{4}\right)$ ranging from 1680 to $1820 \mathrm{~cm}^{-1}$ with a peak magnitude in the $\mathrm{R}$ branch at $1764 \mathrm{~cm}^{-1}$ (Kamat et al., 2007). The nearest recorded line to our target wavelength is a $\mathrm{P}$ branch of the $\mathrm{C}=\mathrm{O}$ stretch at $1725 \mathrm{~cm}^{-1}$ (Kegley-Owen et al., 1999). Because it is far enough from the target, it is unlikely that acetaldehyde influences the $\mathrm{HCHO}$ absorption at $1721 \mathrm{~cm}^{-1}$.

\subsubsection{Calibration, uncertainty, and data reduction}

During the BEARPEX 2007, a permeation tube (Metronics Dynacal; $88 \pm 4 \mathrm{ng} / \mathrm{min}$ at $45^{\circ} \mathrm{C}$ ) diluted with ultra high purity grade zero air (Airgas) was used to calibrate the $\mathrm{HCHO}$ absorption measurements. A simple gravimetric test performed after the campaign confirmed the manufacturer's permeation rate. The permeation tube was initially weighed with a microbalance (Mettler Toledo XP 26; repeatability $\pm 1.5 \mu \mathrm{g}$ ), placed in the oven at $45^{\circ} \mathrm{C}$ with a constant flow of $\mathrm{N}_{2}$ for 5 days, and weighed again to obtain the weight loss rate of $78( \pm 10) \mathrm{ng} / \mathrm{min}$, showing agreement with the reported value within measurement error. The permeation 
tube is held in an oven at a regulated temperature and pressure (typically, $45^{\circ} \mathrm{C}$ and $1856 \mathrm{mbar}$, respectively). The concentrations from the permeation system are calculated from the emission rate of the permeation tube and the flow rates of the dilution and carrier gases through the permeation tube. Further assurance of the calibration source was obtained by using two different permeation tubes with different emission rates $\left(88 \mathrm{ng} / \mathrm{min}\right.$ and $35 \mathrm{ng} / \mathrm{min}$ at $\left.45^{\circ} \mathrm{C}\right)$. The observed absorbances from the two permeation tubes were found to agree, with the two sets of data falling onto one line quite well $\left(R^{2}=0.999\right)$. For the precision test, the spectra for a HCHO standard $(11.8 \mathrm{ppm})$ from the permeation tube in high calibration mode were collected over $15 \mathrm{~min}$ intervals (this excessive amount was used only for coarse spectral line identification and a general check on the linearity of the system). The standard error was $2.1 \%$ using 1-minute average scans. The spectra of HCHO diluted in zero air $(93.3 \mathrm{ppb}$ and $27 \mathrm{ppb}$ ) were also collected yielding $3.9 \%$ and $8.9 \%$ standard error. In order to verify whether ultra high purity (UHP) zero air (additionally purified with a charcoal hydrocarbon trap) contains any trace of $\mathrm{HCHO}$, we compared absorption spectra of zero air between the cell pressure of $1.8 \mathrm{mbar}$ and the operational cell pressure of 60 mbar. If the zero air contained any kind of absorber at the target wavenumber, the spectrum at 60 mbar should show a bigger and broader peak due to its greater density and Lorentz line broadening. However, the spectra between two zero air samples at 1.8 and 60 mbar were nearly identical within $\sim 1 \sigma$ error range for the entire scanned frequency interval. Because we do not expect that a difference in spectral shapes between the two cell pressures would be compensated by changes in the optical structure throughout the entire scanned spectral range, we concluded that the zero air was free of any $\mathrm{HCHO}$ spectral interference.

By far the largest source of instrumental noise was the background spectrum in zero air which drifted and changed its shape throughout the experiment, presumably in response to shifting conditions of the laser and optical train. Spectra in zero air were obtained at least every $8 \mathrm{~h}$, before and after refilling the liquid nitrogen Dewars of the detectors. Assuming that the background spectra change gradually over the $8 \mathrm{~h}$, we obtained 9th order polynomial curve fitting parameters to the background (zero air) spectrum on either end of the ambient air measurement interval. We then interpolate the polynomial coefficients between times of the zero air scans to calculate the expected baseline during the intervening measurements. However, we came to suspect that some baseline changes were further caused by room temperature changes, because the temperature changes may lead to subtle changes in the actual laser mount temperature (despite being controlled to a fixed set point.) In actuality, we found that at some times, the interpolated baseline with time did not reflect the baseline changes in ambient spectra with time, and in such cases, a temperature correction (linear interpolation of fitting curve coefficients with cell temperature) was more effective than the usual time-based correction. Although the $8 \mathrm{~h}$ duration

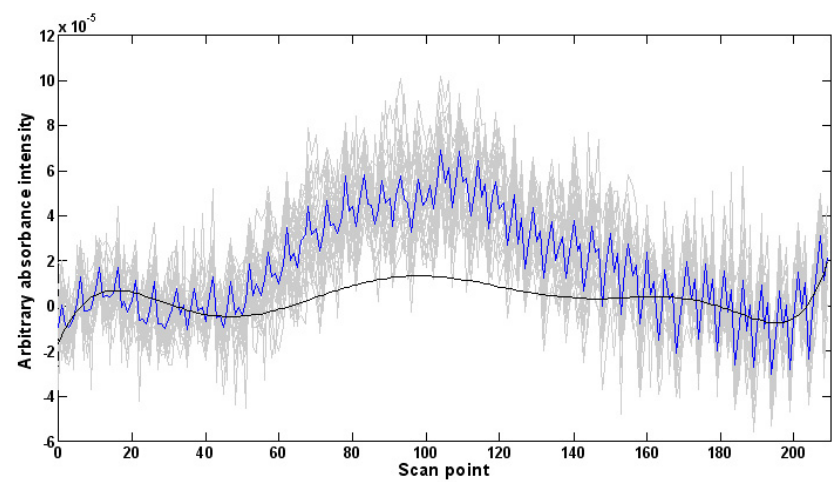

Fig. 2. Example of ambient $10 \mathrm{~s}$ absorption spectra (gray lines) and the $5 \mathrm{~min}$ averaged spectrum (blue line) for 30 samples. The background spectrum (black line) is interpolated from the two zero air spectra obtained before and after the measurement interval.

between zero air acquisitions is not optimal and may miss rapid fluctuations in the background spectra, we came to believe that the background changes were more or less gradual throughout the experiment because the background spectral structure outside of the HCHO absorption feature, observed at the calibration times and during the ambient scans, routinely agreed with each other. In addition, no abrupt jump or dip in ambient $\mathrm{HCHO}$ concentrations was observed, which would be expected were there an abrupt change in the background spectra. However, assuming that an abrupt change in background did occur at some point in between background scans, our best estimate of possible error from this is only about $15 \%$.

HCHO spectra of the ambient air were collected every $10 \mathrm{~s}$ during the campaign, and averaged for $5 \mathrm{~min}$. Then, an interpolated background spectrum, as described above, was subtracted from the $5 \mathrm{~min}$ average spectrum. The area of the background-subtracted spectrum throughout the scanned spectral range $\left(\sim 0.1 \mathrm{~cm}^{-1}\right.$ interval) was finally calculated (which is, hereinafter, called integrated absorbance) for HCHO absorbance. An example of a typical averaged baseline and ambient spectrum is shown in Fig. 2.

Aside from zero-air backgrounds, we further obtained at least one HCHO calibration point from the permeation system every $8 \mathrm{~h}$. We examined the sensitivity variation over the entire experiment as a function of time and further by considering all possible variables that might influence instrument performance (such as cell temperature and pressure, laser mount temperature, sample flow rate) in a multivariate regression analysis. Reproduced sensitivities from the regression analyses agreed well with the observed sensitivities $\left(R^{2}=0.92, N=49\right)$. Observed integrated absorbance of ambient HCHO were calibrated by the derived timedependent sensitivity function taking into account all the operating parameters recorded. Fluctuations in observed sensitivity and the time-dependent sensitivity function during 
Table 1. Other atmospheric species simultaneously observed in this study and research groups who provided the data.

\begin{tabular}{|c|c|c|c|}
\hline Species & Method & Height (Day) & Research Group \\
\hline $\mathrm{OH}$ and $\mathrm{HO}_{2}$ & $\begin{array}{l}\text { Laser Induced } \\
\text { Fluorescence }\end{array}$ & $\begin{array}{l}9.4 \mathrm{~m}(255 \sim 263) \\
15.5 \mathrm{~m}(264 \sim 266) \\
6.4 \mathrm{~m}(266 \sim 267) \\
6.4 \mathrm{~m}(255 \sim 261 ; 266 \sim 267)\end{array}$ & Brune; Penn. State. Univ. \\
\hline $\begin{array}{l}\text { Isoprene, MVK, MACR, MBO, } \\
\text { Ethene, Propene, and } \mathrm{MeOH}\end{array}$ & GC-MS & $\begin{array}{l}9.5 \mathrm{~m}(261 \sim 263 ; 267 \sim 270) \\
15.5 \mathrm{~m}(263 \sim 266)\end{array}$ & De Gouw; NOAA \\
\hline $\begin{array}{l}\alpha \text { - and } \beta \text {-pinene, } \\
\text { limonene, myrcene, } 3 \text {-carene, } \\
\alpha \text { - and } \gamma \text {-terpinene, } \\
\text { terpinolene, linalool, longifolene, } \\
\text { methyl chavicol, and other sesquiterpenes }\end{array}$ & GC-MS & $9.3 \mathrm{~m}$ & $\begin{array}{l}\text { Goldstein; UC Berkely } \\
\text { (Bouvier-Brown et al., 2009a) }\end{array}$ \\
\hline $\mathrm{NO}_{2}$ & TD-LIF & $4.9 \mathrm{~m}$ & $\begin{array}{l}\text { Cohen; UC Berkeley } \\
\text { (LaFranchi et al., 2009) }\end{array}$ \\
\hline PAN & TD-CIMS & $17.7 \mathrm{~m}$ & $\begin{array}{l}\text { Thornton; U. of Washington } \\
\text { (Wolfe et al., 2009) }\end{array}$ \\
\hline Meteorological data & & $12.5 \mathrm{~m}$ & Goldstein; UC Berkely \\
\hline
\end{tabular}

the measurement period are shown in Fig. 3. The average sensitivity of the spectrometer, defined as the integrated absorbance per unit ppb of $\mathrm{HCHO}$ was $2.3 \times 10^{-4} \mathrm{ppb}^{-1}$ with an estimated standard error, resulting from sensitivity variations of $\sim 14 \%$, which is the replicate precision estimate $( \pm 3.5 \mathrm{ppb}$ at $25 \mathrm{ppb})$. Based on errors from permeation rate, linearity between absorbance and concentrations, precision tests, variability in sensitivity, and background drifts, we estimate the uncertainty in the technique to be no more than $25 \%$ of the typical daytime signal. In addition, based on the noise level and the Gaussian fit with the same width as ambient $\mathrm{HCHO}$ spectra, the limit of detection was determined to be $2.1 \mathrm{ppb}(S / N=2)$ during the experiment, which is quite large but sufficient to detect the high concentrations of HCHO encountered at Blodgett Forest.

\subsubsection{Other measurements used in this study}

During the 2007 BEARPEX field intensive, many key species involved in forest photochemistry were simultaneously measured, affording a superb opportunity to investigate the $\mathrm{HCHO}$ chemistry in this coniferous forest. The team measurements used in this analysis include $\mathrm{HO}_{\mathrm{x}}$ $\left(=\mathrm{OH}+\mathrm{HO}_{2}\right)$, biogenic VOCs, $\mathrm{O}_{3}, \mathrm{NO}_{2}$, peroxyacetyl nitrate (PAN), and meteorological data such as temperature, wind speed/direction, $\mathrm{H}_{2} \mathrm{O}$, and PAR (photosynthetically active radiation, which is measured throughout the solar spectral range of 400 to $700 \mathrm{~nm}$ ). The measured atmospheric species, methods, measuring height, and research investigators who provided the data are shown in Table 1.

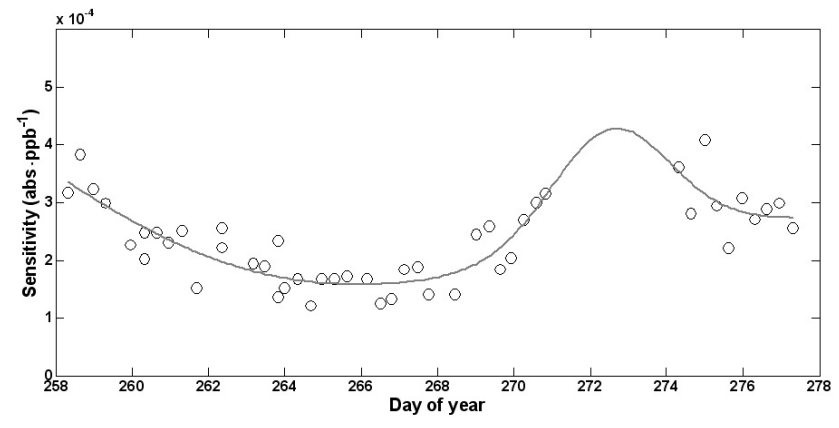

Fig. 3. Observed HCHO sensitivity variation (black circles) and the derived time-dependent sensitivity function using Gaussian fitting curves (gray line) throughout the measurement period. Y-axis is the integrated absorbance of $\mathrm{HCHO}$ per unit ppb.

\section{Results and data analysis}

HCHO was measured from 16 September to 4 October 2007 (Julian days 259-277). During that period the prevailing winds exhibited a strong diurnal cycle, following a typical cross-valley wind system as discussed in detail by Dillon et al. (2002). During the daytime, west-southwesterly anabatic winds predominate with speeds of $2.85 \pm 0.75 \mathrm{~m} / \mathrm{s}$. Reciprocally, the nighttime katabatic winds usually come from the east-northeast direction at lower speeds of $1.1 \pm 0.7 \mathrm{~m} / \mathrm{s}$. The 30-minute averaged timeseries of $\mathrm{HCHO}$, temperature, PAR, representative BVOCs (total monoterpenes, $\mathrm{MBO}$, isoprene, methacrolein), and $\mathrm{HO}_{\mathrm{x}}$ are shown in Fig. 4.

Observed $\mathrm{HCHO}$ concentrations ranged up to the maximum of $20.5 \mathrm{ppb}$ around noontime and showed a consistent decrease at night with a mean overnight low of $0.8 \mathrm{ppb}$ ( $1 \sigma$ of 


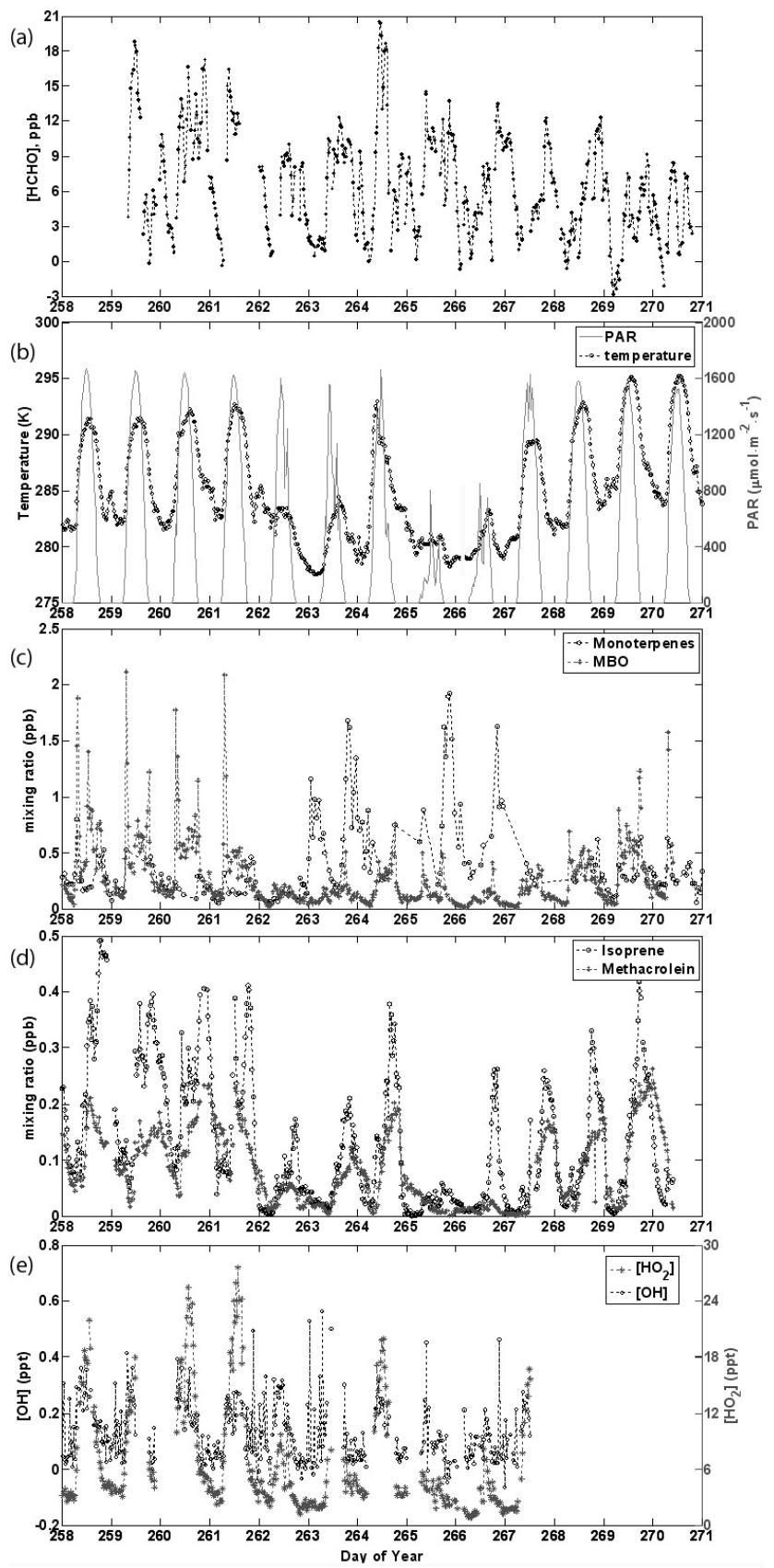

Fig. 4. Timeseries of (a) HCHO, (b) temperature and PAR, (c) total monoterpenes and $\mathrm{MBO}$, (d) isoprene and methacrolein, and (e) $\mathrm{HO}_{\mathrm{x}}$ during days $258 \sim 271$ of BEARPEX 2007. All data points are $30 \mathrm{~min}$ average.

$0.9 \mathrm{ppb}$ ) just before sunrise (Fig. 5a). Based on the timeseries of $\mathrm{HCHO}$, we split our analysis into two different periods: high HCHO (doy 259 261 and 264, hereinafter referred to as the High phase) and lower HCHO (doy $262 \sim 263$ and $265 \sim 277$, hereinafter Low phase) when it was relatively wet with a few intermittent rainfall events. Interestingly, the diurnal profiles of HCHO show distinct patterns in High and Low
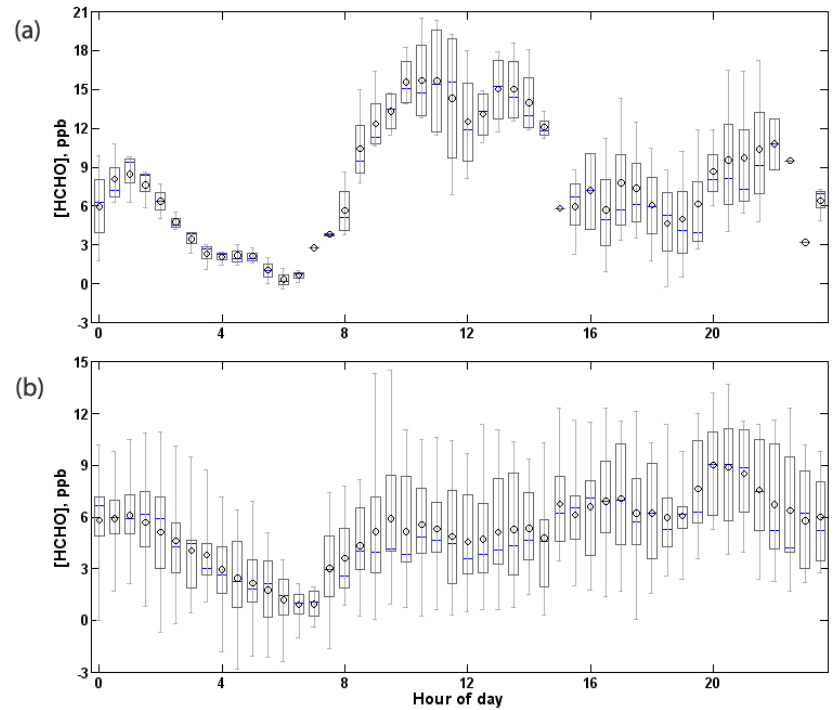

Fig. 5. Box plots of the average diurnal HCHO concentration patterns observed during BEARPEX 2007. The upper plot is for the High phase (days $259 \sim 261$ and 264) and the bottom plot is the Low phase $(262 \sim 263$ and $265 \sim 277)$ during which there were occasional rain and snowfall events. $50 \%$ of observed data is distributed within each 30 min box and vertical bars denote maximum and minimum. Black circles and blue horizontal bars represent mean and median, respectively. Average daytime $(10: 00 \sim 16: 00)[\mathrm{HCHO}]=$ $7.3 \pm 0.8 \mathrm{ppb}$ for the entire measurement period.

phases (Fig. 5). During the High phase, HCHO concentrations started increasing sharply immediately after sunrise and attained a midday peak with a smaller, secondary peak in the evening around 20:00. However, during the Low phase, although the rise in the $\mathrm{HCHO}$ concentration after sunrise was observed, the midday peak was significantly suppressed and gives way to a continued build-up throughout the day until early evening. In fact, an evening peak of just under $10 \mathrm{ppb}$ occurred near 20:00 in both periods. The decrease in midday HCHO concentrations in the Low phase is likely related to suppressed photochemistry and BVOC emissions during those days. Therefore, our discussion about the HCHO budget will proceed based on two different periods: the High and Low phases. Nevertheless, in both phases, a consistent decrease in overnight $\mathrm{HCHO}$ was observed until dawn most likely due to dry deposition within a shallow nocturnal boundary layer.

Figure 6 shows the mean diurnal profiles of meteorological data during the High and Low phases. The most pronounced differences between the two periods are observed in air temperature, particularly in the morning and early afternoon (08:00 13:00), and also in insolation (actually measured PAR), whose midday peak is lower by $15-20 \%$ in the Low phase. On the other hand, no observable difference in wind speed or direction was found, save for perhaps a slight increase in predawn katabatic winds during the Low phase. 

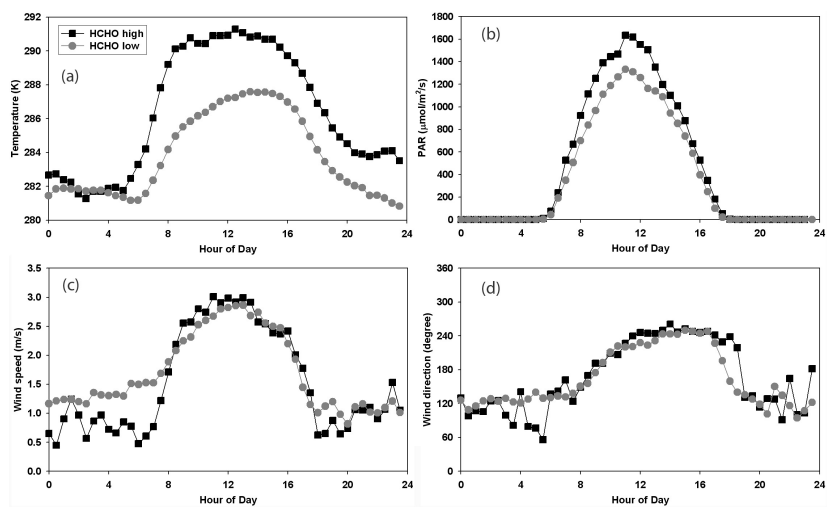

Fig. 6. Mean diurnal profiles of (a) temperature (K), (b) PAR $\left(\mu \mathrm{mol} \mathrm{m} \mathrm{m}^{-2} \mathrm{~s}^{-1}\right)$, (c) wind speed $\left(\mathrm{m} \mathrm{s}^{-1}\right)$, and (d) wind direction ( $0^{\circ}$ to North) during HCHO High (dark squares; $259 \sim 261$ and 264) and Low phases (gray circles; $262 \sim 263$ and $265 \sim 277$ ) of BEARPEX 2007.

In spite of significant changes in the mean diurnal patterns of temperature between the two phases, temperature does not seem to be the dominant control on HCHO levels because relatively lower HCHO was observed during the higher temperatures for doy $268 \sim 270$ and later doy 275-276 (Fig. 4). The mean diurnal patterns of $\mathrm{O}_{3}$, another secondary photochemical product, showed a marked difference from those of HCHO during the High period. The ozone builds gradually throughout the day reaching a peak in the late afternoon around 16:00 with no evening peak near 20:00 as $\mathrm{HCHO}$ shows, whereas the daytime HCHO peak appears between 11:00 and 13:00 about $4 \mathrm{~h}$ before the ozone peak, implying that $\mathrm{HCHO}$ and $\mathrm{O}_{3}$ have different sources and sinks in this region (Fig. 7e) during the High period. On the other hand, the HCHO diurnal profile during the Low period exhibits a build-up very similar to $\mathrm{O}_{3}$, indicating that the local concentrations of both species are predominantly controlled by advection of the Sacramento plume during the Low period. A similar steady daytime rise is seen in other species known to advect into the region such as $\mathrm{NO}_{\mathrm{x}}$, benzene, and isoprene (Figs. 7 and 8b; Day et al., 2009), although $\mathrm{O}_{3}$ tends to peak earlier than the rest at 16:00 probably due to its active photochemical production during the afternoon. Averaged diurnal patterns of $\mathrm{HO}_{\mathrm{x}}$ support daytime enhanced $\mathrm{HCHO}$ during the High period. Daytime $\mathrm{HO}_{2}$ during the High phase is 2-4 times as large as the Low phase, whereas $\mathrm{OH}$ shows no remarkable difference between the two phases (Fig. $7 \mathrm{~g}$ and $\mathrm{h}$ ). Considering that $\mathrm{HCHO}$ is a major source of $\mathrm{HO}_{2}$, enhanced $\mathrm{HO}_{2}$ during the High period is likely linked to the abundant daytime $\mathrm{HCHO}$.

$\mathrm{NO}$ abundance regulates $\mathrm{HO}_{\mathrm{x}}$ cycling, thereby affecting secondary photochemical products such as $\mathrm{O}_{3}$ and $\mathrm{HCHO}$. For example, HCHO yields, in many cases, strongly depend on the abundance of NO in the surroundings. Unfortunately, NO was not directly measured during BEARPEX
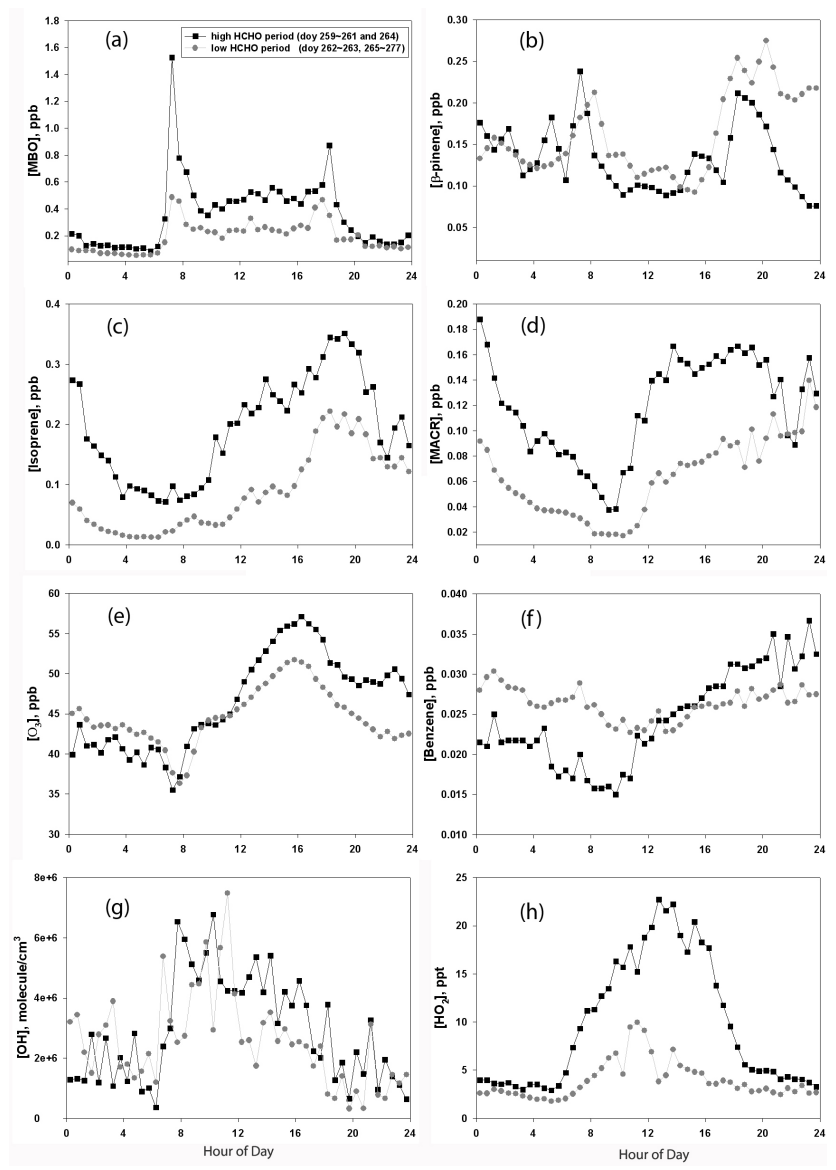

Fig. 7. Mean diurnal profiles of (a) $[\mathrm{MBO}(\mathrm{ppb})]$, (b) $[\beta$-pinene (ppb)], (c) [isoprene (ppb)], (d) [MACR (ppb)], (e) [O $\left.\mathrm{O}_{3}(\mathrm{ppb})\right]$, (f) [benzene $(\mathrm{ppb})],(\mathbf{g})\left[\mathrm{OH}\left(\right.\right.$ molecule $\left.\left./ \mathrm{cm}^{3}\right)\right]$, and (h) $\left[\mathrm{HO}_{2}(\mathrm{ppt})\right]$ for the High (dark squares; 259 261 and 264) and the Low phases (gray circles; $262 \sim 263$ and $265 \sim 277$ ) of BEARPEX. The data is sorted into $30 \mathrm{~min}$ bins.

2007. Therefore, [NO] was estimated from a $\mathrm{HO}_{2}-\mathrm{RO}_{2}-\mathrm{NO}-$ $\mathrm{NO}_{2}-\mathrm{O}_{3}$ photostationary state relationship assuming $\left[\mathrm{HO}_{2}\right]$ $\approx\left[\mathrm{RO}_{2}\right]$ in this study. The resultant expression for $[\mathrm{NO}]_{\mathrm{ss}}$ is shown in Eq. (2), where $k_{\mathrm{O}_{3}-\mathrm{NO}}=1.4 \times 10^{-12} \times \mathrm{e}^{-1310 / T}$, $k_{\mathrm{HO}_{2}-\mathrm{NO}}=3.6 \times 10^{-12} \times \mathrm{e}^{270 / T}$ (Atkinson et al., 2004), and $k_{\mathrm{RO}_{2}-\mathrm{NO}}=2.7 \times 10^{-12} \times \mathrm{e}^{360 / T}$ (Atkinson, 1997). [ $\left[\mathrm{NO}_{2}\right]$, $\left[\mathrm{HO}_{2}\right]$ and $\left[\mathrm{O}_{3}\right]$ were obtained from the measurements at Blodgett Forest. $j_{\mathrm{NO}_{2}}$ was estimated from the TUV model v.4.5 (NCAR, 2008) and scaled by observed PAR (Appendix A).

$[\mathrm{NO}]_{\mathrm{ss}}=\frac{j_{\mathrm{NO}_{2}}\left[\mathrm{NO}_{2}\right]}{k_{\mathrm{O}_{3}-\mathrm{NO}}\left[\mathrm{O}_{3}\right]+k_{\mathrm{RO}_{2}-\mathrm{NO}}\left[\mathrm{RO}_{2}\right]+k_{\mathrm{HO}_{2}-\mathrm{NO}}\left[\mathrm{HO}_{2}\right]}$

Due to a lack of overlapping $\mathrm{NO}_{2}$ data with the $\mathrm{HCHO}$ measurements, diurnally averaged $\mathrm{NO}_{\mathrm{x}}$ was used in this study for the period from Julian day 258-278. As shown in Fig. (8a), photostationary NO increases sharply immediately after sunrise due to an increase in $\left[\mathrm{NO}_{2}\right]$ presumably from mixing down (fumigation) of the previous day's mixed 


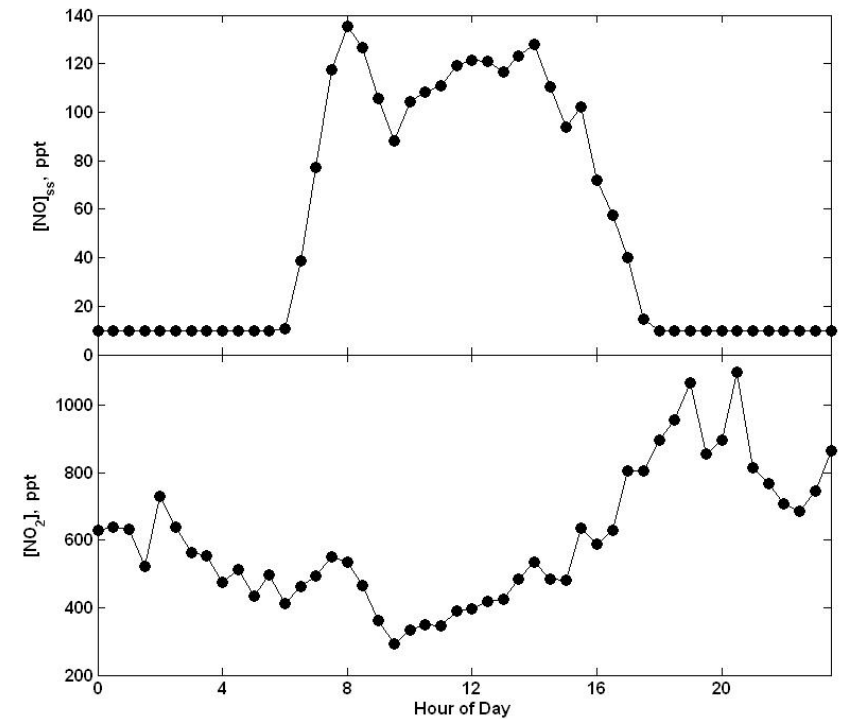

Fig. 8. Mean diurnal patterns of calculated [NO] and observed $\left[\mathrm{NO}_{2}\right]$. $[\mathrm{NO}]_{\mathrm{ss}}$ was estimated assuming $\mathrm{NO}-\mathrm{NO}_{2}-\mathrm{HO}_{2}-\mathrm{RO}_{2}-\mathrm{O}_{3}$ photostationary state with $\left[\mathrm{RO}_{2}\right]=\left[\mathrm{HO}_{2}\right] .\left[\mathrm{NO}_{2}\right]$ was measured with TD-LIF by the UC Berkeley research group.

(residual) layer and the rise of actinic radiation. It then remains nearly constant around 120 ppt until 14:00 and then gradually falls off due to the diminution of solar radiation, although the total $\mathrm{NO}_{\mathrm{x}}$ continues to build throughout the afternoon due to advection of the Sacramento plume (Fig. 8b). Nighttime $[\mathrm{NO}]_{\mathrm{ss}}$ was not able to be estimated from photostationary state, and hence assumed to be $10 \mathrm{ppt}$ (Day et al., 2009; Dillon et al., 2002). Although $\left[\mathrm{RO}_{2}\right]$, assumed equal to the observed $\left[\mathrm{HO}_{2}\right]$, influences the steady state $[\mathrm{NO}]_{\mathrm{ss}}$ estimation, the sensitivity of $[\mathrm{NO}]_{\mathrm{ss}}$ to a change in assumed $\left[\mathrm{RO}_{2}\right]$ is not very large: merely a $10 \%$ difference in $[\mathrm{NO}]_{\mathrm{ss}}$ for a doubling of $\left[\mathrm{RO}_{2}\right]\left(=2 \times\left[\mathrm{HO}_{2}\right]\right)$.

\subsection{Observed formaldehyde sinks and inferred dry deposition}

Our initial goal is to first broadly characterize the processes responsible for the observed diurnal patterns in HCHO. In this section, we discuss $\mathrm{HCHO}$ sinks from observations. Photolysis is a major daytime sink of $\mathrm{HCHO}$ that ultimately produces nearly an equivalent of hydroperoxy $\left(\mathrm{HO}_{2}\right)$ radicals via subsequent Reactions (R1-R3). Under conditions with relatively high concentrations of $\mathrm{HCHO}$ and low UV fluxes (near sea level and at high solar zenith angles), HCHO is one of the most important sources of hydroperoxy radicals in the atmosphere.

$$
\begin{aligned}
& \mathrm{HCHO}+h v \stackrel{\lambda<330 \mathrm{~nm}}{\longrightarrow} \mathrm{H} \cdot+\mathrm{HCO} \cdot(45 \%) \\
& \stackrel{\lambda<330 \mathrm{~nm}}{\longrightarrow} \mathrm{H}_{2}+\mathrm{CO}(55 \%)
\end{aligned}
$$

$\mathrm{H} \cdot+\mathrm{O}_{2}$ $\longrightarrow \mathrm{HO}_{2}$.
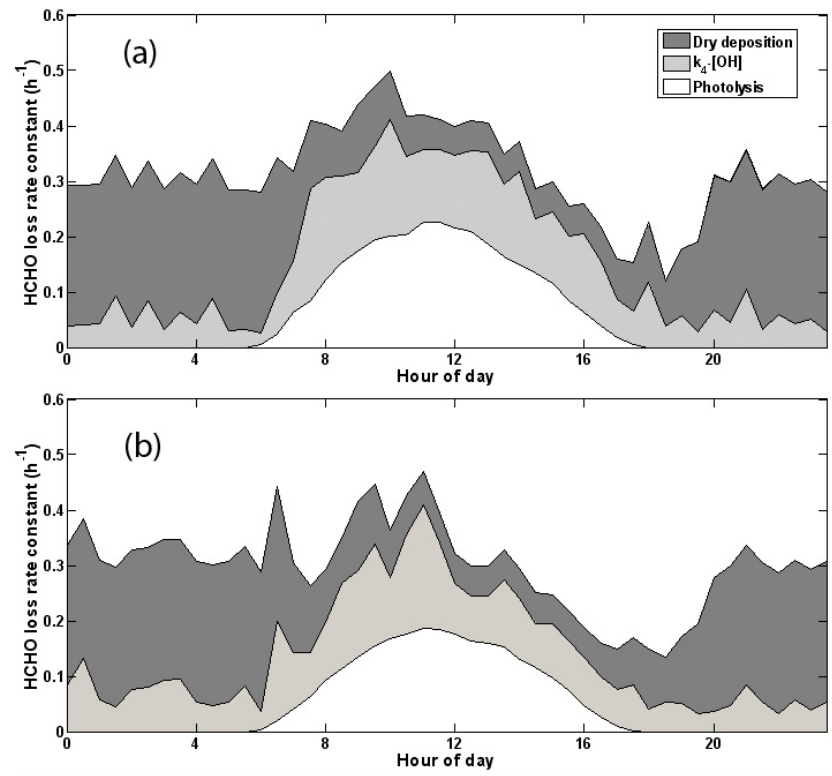

Fig. 9. Mean diurnal variations of the first order $\mathrm{HCHO}$ loss rate constants $\left(\mathrm{h}^{-1}\right)$ for photolysis $\left(j_{1 \mathrm{a}}+j_{1 \mathrm{~b}}\right)$ (white), reaction with $\mathrm{OH}$ $\left(k_{4} \cdot[\mathrm{OH}]\right)$ (light gray), and dry deposition (dark gray) in (a) $\mathrm{HCHO}$ High period and (b) HCHO Low period of BEARPEX 2007.

$\mathrm{HCO} \cdot+\mathrm{O}_{2} \longrightarrow \mathrm{HO}_{2} \cdot+\mathrm{CO}$

The overall HCHO loss rate by photolysis can be obtained from measured $\mathrm{HCHO}$ concentrations and its photolysis rate constants, $j_{1 \mathrm{a}}$ and $j_{1 \mathrm{~b}}$, which were parameterized by the observed PAR using the TUV model, similar to the estimate of $j_{\mathrm{NO}_{2}}$ (Appendix A).

Direct reaction with hydroxyl radicals $\left(k_{4}=5.4 \times 10^{-12} \times \mathrm{e}^{135 / T}\right.$; Atkinson et al., 2006) is another major $\mathrm{HCHO}$ removal processes in the atmosphere, also producing $\mathrm{HO}_{2}$ (Reactions R3 and R4). Generally speaking, diurnal average $\mathrm{OH}$ concentrations at Blodgett Forest rapidly increase immediately after sunrise, peaking near 11:00 with a maximum of $0.27 \mathrm{ppt}\left(5.9 \times 10^{6}\right.$ molecules $\left.\mathrm{cm}^{-3}\right)$, and decreasing thereafter but not dropping below $0.05 \mathrm{ppt}$, which is equivalent to $1.2 \times 10^{6}$ molecules $\mathrm{cm}^{-3}$, even throughout the night. The mean concentration of nighttime $\mathrm{OH}$ for 22:00 06:00 is $0.084 \pm 0.03 \mathrm{ppt}$, or $1.9 \times 10^{6}$ molecules $\mathrm{cm}^{-3}$ (Fig. $7 \mathrm{~g}$ ). Such elevated nocturnal $\mathrm{OH}$ has been observed before in forested environments with small local NO emissions (Faloona et al., 2001), and has been proposed to be the result of the ozonolysis of reactive BVOCs. Considering this relatively high and consistent $[\mathrm{OH}]$, the first-order nighttime $\mathrm{HCHO}$ loss rate constant due to $\mathrm{OH}$ was significant, accounting for about $20 \%$ of total $\mathrm{HCHO}$ sinks $\left(0.06 \pm 0.01 \mathrm{~h}^{-1}\right)$ (Fig. 9).

$\mathrm{HCHO}+\mathrm{OH} \cdot \longrightarrow \mathrm{H}_{2} \mathrm{O}+\mathrm{HCO}$. 
Dry deposition is typically the most important nocturnal removal process controlling $\mathrm{HCHO}$ variation when, compared with daytime, photochemical production is less important and $\mathrm{OH}$ is a less effective sink (Sumner et al., 2001). Observed nighttime HCHO showed a consistent decline in both the High and Low periods, implying that HCHO losses predominate and remain steady overnight mainly due to dry deposition, as long as advection is not a significant contributor. While, in reality, our estimation of the total nocturnal $\mathrm{HCHO}$ production from all BVOC precursors considered in this study is non-negligible (mean $0.29 \pm 0.07 \mathrm{ppb} \mathrm{h}^{-1}$ during 22:00 04:00), resulting from both the elevated nighttime $\mathrm{OH}$ and the temperature-dependent emissions of BVOCs such as monoterpenes (Bouvier-Brown et al., 2009a), the magnitude of production is largely balanced by loss to $\mathrm{OH}$ $\left(0.32 \pm 0.02 \mathrm{ppb} \mathrm{h}^{-1}\right)$ in the budget equation. Thus the assumption that dry deposition is the primary sink of $\mathrm{HCHO}$ during night remains effectively valid. Because the nocturnal boundary layer depth is critical to estimating the nighttime dry deposition velocity, a comparative method with nighttime ozone decay rates is used to circumvent the unobserved nocturnal boundary layer depth as in previous studies (Shepson et al., 1992; Sumner et al., 2001). Assuming that nocturnal production and loss from $\mathrm{OH}$ cancel, we calculate the first-order loss rate constant from the averaged logarithmic [HCHO] decay during the middle of the night $(01: 00 \sim 04: 00)$ to be $-0.27 \mathrm{~h}^{-1}$. Scaling the nighttime ozone dry deposition velocity observed for the same season by Kurpius et al. (2002), $0.05 \mathrm{~cm} \mathrm{~s}^{-1}$, to the measured $\mathrm{O}_{3}$ decay of $-0.016 \mathrm{~h}^{-1}$ yields a HCHO dry deposition rate of $0.84 \mathrm{~cm} \mathrm{~s}^{-1}$. This nighttime rate is similar to those from Sumner et al. (2001) and Krinke and Wahner (1999), $0.65 \mathrm{~cm} \mathrm{~s}^{-1}$ and $0.75 \mathrm{~cm} \mathrm{~s}^{-1}$, respectively, and implies a nocturnal boundary layer mixing depth at Blodgett Forest of about $110 \mathrm{~m}$. We use a value of $1.5 \mathrm{~cm} \mathrm{~s}^{-1}$, as in Sumner et al. (2001) and Krinke and Wahner (1999), for the daytime dry deposition velocity in our time-dependent HCHO model described below.

By our estimation the role of $\mathrm{HO}_{2}$ and $\mathrm{NO}_{3}$ in $\mathrm{HCHO}$ removal at Blodgett is negligible (Appendix $\mathrm{B}$ ). The overall first-order loss rate constants $\left(\mathrm{h}^{-1}\right)$ of $\mathrm{HCHO}$, calculated from the observed $\mathrm{OH}$, photolysis frequencies scaled to observed PAR, and dry deposition as discussed above are shown in Fig. 9 for the High and Low phases. In general, a maximum at 10:30 is influenced both by the maximum $\mathrm{OH}$ concentrations near 10:00 and by the peak photolysis rate constant at 11:00 PST, accounting for 37\% and 47\% of total loss rate (10:00 14:00), respectively, in both the High and Low periods. The difference in overall losses between the two periods is less than $20 \%$, implying that the dramatic difference of daytime HCHO levels between the two periods is determined by the sources.

\subsection{Known HCHO production from VOC observations}

$\mathrm{HCHO}$ is secondarily produced in the atmosphere through the oxidation of various VOCs by oxidants such as $\mathrm{OH}$, $\mathrm{O}_{3}$, and $\mathrm{NO}_{3}$. Therefore, with the known $\mathrm{HCHO}$ yields of those oxidation processes and the concentrations of the parent VOC's and oxidants, the chemical production rate can be estimated as shown in Eq. (3), where $i$ denotes a species of oxidant such as $\mathrm{OH}$ or $\mathrm{O}_{3}, j$ denotes a species of VOC that produces HCHO through its oxidation, and $k_{i j}$ and $\gamma_{i j}$ represent the reaction rate coefficients and $\mathrm{HCHO}$ yields for the reaction between oxidant $i$ and $\mathrm{VOC}_{j}$, respectively.

$$
P_{k_{i j}}=\sum_{i} \sum_{j}\left(\gamma_{i j} k_{i j}[\mathrm{VOC}]_{j}[\text { Oxidant }]_{i}\right)
$$

\subsubsection{OH-initiated HCHO production}

Among the numerous BVOCs known to yield HCHO upon reaction with $\mathrm{OH}, 17$ representative hydrocarbons observed by GC/MS during BEARPEX, including monoterpenes $(\alpha$ - and $\beta$-pinene, myrcene, limonene, 3-carene, terpinolene, $\alpha$ - and $\gamma$-terpinene), isoprene, 2-methyl-3-buten-2-ol (MBO), methyl vinyl ketone (MVK), methacrolein (MACR), methanol, longifolene, methyl chavicol, ethene, and propene, were used in calculating $\mathrm{HCHO}$ production rates. Although the $\mathrm{HCHO}$ yield from isoprene oxidation is relatively well understood (Appendix $\mathrm{C} 1$ ), the $\mathrm{NO}_{\mathrm{x}}$ dependence of $\mathrm{HCHO}$ yields is not well established for most other biogenic VOCs, and hence, the fixed yields derived from chamber experiments in the presence of NO reported in the literature were used in this study (Atkinson and Arey, 2003; Griffin et al., 1999; Hoffmann et al., 1997; Lee et al., 2006b; Sumner et al., 2001; Tuazon and Atkinson, 1990; Paulot et al., 2009) as summarized in Table 2.

The mean diurnal patterns of overall $\mathrm{OH}$-initiated $\mathrm{HCHO}$ production from known BVOC sources show significant differences between the High and Low periods (Fig. 10). During the High period, $\mathrm{HCHO}$ production rates display a strong diurnal cycle with the first maximum in the early morning and the second peak in the early afternoon, whereas no remarkable diurnal patterns are evident in the Low period. The mean daytime (10:00 16:00) magnitude in HCHO production is reduced from $0.73 \pm 0.12 \mathrm{ppbh}^{-1}$ in the High to $0.28 \pm 0.14 \mathrm{ppb} \mathrm{h}^{-1}$ in the Low period. The sudden surge of $\mathrm{HCHO}$ production in the early morning of the High period is the result of the drastic rise in both $\mathrm{OH}$ and BVOCs (BouvierBrown et al., 2009a). Although OH tends to steadily decrease after its peak around 10:30, the increase or persistence of the BVOC concentrations maintains a similar HCHO production through the late afternoon. The detailed atmospheric behavior of BVOCs at Blodgett Forest, depending on the types of emission and mixed layer height, are described in detail by Bouvier-Brown et al. (2009a). Enhanced OH concentrations at night combined with nocturnal emissions of 
Table 2. Reaction rate constants $k$ for reaction of biogenic VOCs with $\mathrm{OH}$ and $\mathrm{HCHO}$ yields.

\begin{tabular}{|c|c|c|c|}
\hline & $\mathrm{k}\left(\mathrm{cm}^{3} \text { molecule }{ }^{-1} \mathrm{~s}^{-1}\right)^{\mathrm{d}}$ & $\begin{array}{r}\mathrm{HCHO} \\
\text { yield }^{\mathrm{e}}\end{array}$ & Reference \\
\hline Isoprene & $2.7 \times 10^{-11} \times \exp (390 / T)$ & $0.55^{\mathrm{a}}$ & Atkionson $(2006)^{\text {d }}$; estimate ${ }^{\mathrm{e}}$ \\
\hline MBO & $8.2 \times 10^{-12} \times \exp (610 / T)$ & $0.32^{\mathrm{b}}$ & $\begin{array}{l}\text { Atkionson }(2006)^{\mathrm{d}} \\
\text { Alvarado et al. }(1999)^{\mathrm{e}} \\
\text { Ferronato et al. }(1998)^{\mathrm{e}}\end{array}$ \\
\hline MVK & $2.6 \times 10^{-12} \times \exp (610 / T)$ & $0.28^{\mathrm{c}}$ & $\begin{array}{l}\text { Atkionson }(2006)^{\mathrm{d}} \text {; } \\
\text { Tuazon and Atkinson }(1990)^{\mathrm{e}} \text {; } \\
\text { Paulot et al. }(2009)^{\mathrm{e}}\end{array}$ \\
\hline MACR & $8.0 \times 10^{-12} \times \exp (380 / T)$ & 0.61 & $\begin{array}{l}\text { Atkionson }(2006)^{\mathrm{d}} \text {; } \\
\text { Tuazon and Atkinson }(1990)^{\mathrm{e}} \text {; } \\
\text { Paulot et al. (2009) }\end{array}$ \\
\hline$\alpha$-pinene & $1.2 \times 10^{-11} \times \exp (440 / T)$ & 0.19 & 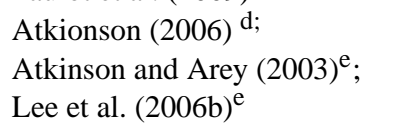 \\
\hline$\beta$-pinene & $7.89 \times 10^{-11}$ & 0.51 & $\begin{array}{l}\text { Atkinson and Arey }(2003)^{\mathrm{d}, \mathrm{e}} \\
\text { Lee et al. }(2006 \mathrm{~b})^{\mathrm{d}, \mathrm{e}}\end{array}$ \\
\hline Myrcene & $2.14 \times 10^{-10}$ & 0.52 & $\begin{array}{l}\text { Atkinson and Arey }(2003)^{\mathrm{d}, \mathrm{e}} \\
\text { Lee et al. }(2006 \mathrm{~b})^{\mathrm{d}, \mathrm{e}}\end{array}$ \\
\hline Methanol & $9.00 \times 10^{-13}$ & 1.0 & $\begin{array}{l}\text { Atkionson }(2006)^{\mathrm{d}} \\
\text { Atkinson et al. }(1999)^{\mathrm{e}}\end{array}$ \\
\hline Methyl chavicol & $5.40 \times 10^{-11}$ & 0.52 & $\begin{array}{l}\text { Bouvier-Brown et al. }(2009 a)^{d} \text {; } \\
\text { Lee et al. }(2006 b)^{\text {e }}\end{array}$ \\
\hline Limonene & $1.71 \times 10^{-10}$ & 0.47 & $\begin{array}{l}\text { Atkinson and Arey }(2003)^{\mathrm{d}} \text {; } \\
\text { Lee et al. } 2006 \mathrm{~b}^{\mathrm{e}} \\
\text { Sumner et al. }(2001)^{\mathrm{e}}\end{array}$ \\
\hline 3-carene & $8.68 \times 10^{-11}$ & 0.28 & $\begin{array}{l}\text { Atkinson and Arey }(2003)^{\mathrm{d}, \mathrm{e}} \text {; } \\
\text { Lee et al. }(2006 \mathrm{~b})^{\mathrm{d}, \mathrm{e}}\end{array}$ \\
\hline Terpinolene & $2.25 \times 10^{-10}$ & 0.26 & $\begin{array}{l}\text { Atkinson and Arey }(2003)^{\mathrm{d}, \mathrm{e}} \text {; } \\
\text { Lee et al. }(2006 \mathrm{~b})^{\mathrm{d}, \mathrm{e}}\end{array}$ \\
\hline$\alpha$-terpinene & $3.62 \times 10^{-10}$ & 0.078 & $\begin{array}{l}\text { Atkinson and Arey }(2003)^{\mathrm{d}, \mathrm{e}} \\
\text { Lee et al. }(2006 \mathrm{~b})^{\mathrm{d}, \mathrm{e}}\end{array}$ \\
\hline$\gamma$-terpinene & $1.77 \times 10^{-10}$ & 0.17 & $\begin{array}{l}\text { Atkinson and Arey }(2003)^{\mathrm{d}, \mathrm{e}} \text {; } \\
\text { Lee et al. }(2006 \mathrm{~b})^{\mathrm{d}, \mathrm{e}}\end{array}$ \\
\hline Longifolene & $4.79 \times 10^{-11}$ & 0.25 & $\begin{array}{l}\text { Atkinson and Arey }(2003)^{\mathrm{d}} \text {; } \\
\text { Lee et al. }(2006 \mathrm{~b})^{\mathrm{e}}\end{array}$ \\
\hline Ethene & $\begin{array}{l}8.6 \times 10^{-29}(T / 300)^{-3.1}\left[\mathrm{~N}_{2}\right]\left(\mathrm{k}_{0}\right) \\
9.0 \times 10^{-12}(T / 300)^{-0.85}\left(\mathrm{k}_{\infty}\right) \\
\mathrm{Fc}=0.48\end{array}$ & 1.8 & $\begin{array}{l}\text { Atkionson }(2006)^{\mathrm{d}} \\
\text { Sumner et al. }(2001)^{\mathrm{e}}\end{array}$ \\
\hline Propene & $\begin{array}{l}8.0 \times 10^{-27}(T / 300)^{-3.5}\left[\mathrm{~N}_{2}\right]\left(\mathrm{k}_{0}\right) \\
3.0 \times 10^{-11}(T / 300)^{-1}\left(\mathrm{k}_{\infty}\right) \\
\mathrm{Fc}=0.5\end{array}$ & 1.0 & $\begin{array}{l}\text { Atkionson }(2006)^{\mathrm{d}} \text {; } \\
\text { Sumner et al. }(2001)^{\mathrm{e}}\end{array}$ \\
\hline
\end{tabular}

a Yield does not include the yield from its oxidation products such as MVK and MACR. (See Appendix C1)

b Averaged HCHO yield (0.29 from Alvarado et al. (1999) and 0.35 from Ferronato et al. (1998). Fantechi et al. (1998) reported 0.09 as HCHO yield, but we did not include this value above due to the large discrepancy with others.

c Total HCHO yield for MVK is 0.58 (Tuazon and Atkinson, 1990); however, we deal with the HCHO yield directly from the oxidation of MVK by OH here, because we also consider MVK's effect on HCHO production from PA radical.

${ }^{\mathrm{d}}$ Reference for reaction constants.

e Reference for HCHO yields. 


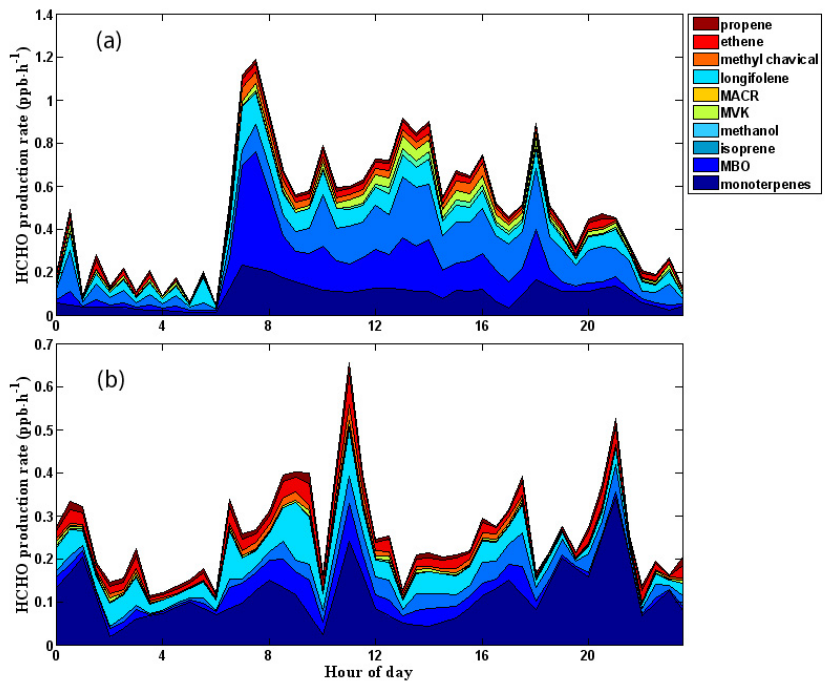

Fig. 10. Mean diurnal variations of $\mathrm{HCHO}$ production rates $\left(\mathrm{ppb} \mathrm{h}^{-1}\right)$ from the $\mathrm{OH}$-initiated oxidation of 17 measured BVOCs (total monoterpenes ( $\alpha$-pinene, $\beta$-pinene, myrcene, limonene, 3 carene, terpinolene, $\alpha$-terpinene, and $\gamma$-terpinene), MBO, isoprene, methanol, MVK, MACR, methyl chavicol, longifolene, ethane, and propene) in (a) HCHO High period and (b) HCHO Low period.

terpenes and $\mathrm{CH}_{3} \mathrm{OH}$ lead to considerable $\mathrm{HCHO}$ production $\left(0.21 \pm 0.06 \mathrm{ppbh}^{-1}\right.$ in both periods) at night. During the daytime $(10: 00 \sim 16: 00)$ when $\mathrm{OH}$-initiated $\mathrm{HCHO}$ production is most active, the main contributions are made by monoterpenes $(16 \%, 32 \%)$, MBO $(24 \%, 14 \%)$, isoprene $(29 \%, 14 \%)$, and methanol $(13 \%, 18 \%)$, together accounting for about $80 \%$ of the total known $\mathrm{OH}$-initiated production (High, Low phases.)

\subsubsection{Ozone-initiated HCHO production}

Thirteen BVOCs, including monoterpenes ( $\alpha$ - and $\beta$-pinene, myrcene, 3-carene, terpinolene, $\alpha$-terpinene, limonene), MBO, isoprene, linalool, ethene, propene, and methyl chavicol, are included in the estimate of ozonolytic production. The HCHO yields from the ozonolysis of BVOCs and their reaction rate constants used in this estimate are described in Table 3. The mean diurnal variation of the overall $\mathrm{HCHO}$ production due to ozonolysis shows a maximum around 18:00 due to the $\left[\mathrm{O}_{3}\right]$ peak in conjunction with BVOC diurnal variations. The main known contributors to $\mathrm{HCHO}$ production when ozonolysis is most active (16:00 20:00) were monoterpenes, $\mathrm{MBO}$, and isoprene accounting for $47 / 59 \%$, $19 / 14 \%$, and $25 / 17 \%$ of the total $\mathrm{O}_{3}$-initiated production from known BVOCs during the High/Low period, respectively.

The HCHO production rate resulting from the 13 observed BVOCs $+\mathrm{O}_{3}$ reactions is an order of magnitude smaller than the contributions of known $\mathrm{OH}$-initiated oxidation processes. Assuming a $\mathrm{HCHO}$ yield of $20 \%$, five sesquiterpenes $(\alpha-$ bergamotene, $\alpha$-farnesene, $\beta$-farnesene, and 2 unidentified) measured during BEARPEX lead to a $40 \%$ increase in the total $\mathrm{HCHO}$ production from daytime BVOC ozonolysis, still an inisignificant source, but the measurement was made above the canopy at $9.5 \mathrm{~m}$. It should be noted that BouvierBrown et al. (2009a) found strong intra-canopy concentration gradients of sesquiterpenes due to their high reactivity $\left(\tau_{\mathrm{O}_{3}} \sim 4 \mathrm{~min}\right)$, therefore using sesquiterpene concentrations measured above canopy may lead to significant underestimation of intra-canopy HCHO production. In addition, very reactive species like $\beta$-caryophyllene, which reacts with $\mathrm{O}_{3} \quad 100 \sim 10000$ times faster than those BVOCs observed $\left(\tau_{\mathrm{O}_{3}} \sim 1\right.$ min with $\left[\mathrm{O}_{3}\right]=55 \mathrm{ppb}$; Atkinson and Arey, 2003) and has a HCHO yield of 0.11 (Calogirou et al., 1997; Atkinson and Arey, 2003; Grosjean et al., 1993b), were not measured during BEARPEX due to their extremely high reactivity. Although the $\mathrm{HCHO}$ yield from $\beta$-caryophyllene ozonolysis is not very large, OH-initiated oxidation of this compound can further produce $\mathrm{HCHO}$ with a yield of 0.42 (Lee et al., 2006b). The lifetime of $\beta$-caryophyllene with respect to daytime $\mathrm{OH}$ is about $14 \mathrm{~min}$, which could yield $\mathrm{HCHO}$ production comparable to that from ozonolysis. In addition, considering that $\beta$-caryophyllene is a compound known to be emitted in significant quantities from manzanita branches and that manzanita accounts for $29 \%$ of total leaf area at Blodgett Forest as of 2003 (Bouvier-Brown et al., 2009b), $\beta$-caryophyllene cannot be ruled out as a $\mathrm{HCHO}$ precursor to some degree at least in Blodgett Forest. Consequently, the possibility remains that such unrecognized species may exist in the environment and could contribute significantly to the overall $\mathrm{HCHO}$ production. In fact, a recent branch enclosure study of BVOC emissions from Blodgett forest (Bouvier-Brown et al., 2009b) indicates that there are considerable sesquiterpene emissions at the site which are mostly oxidized before they can be observed in ambient air. Further discussion of the possible effects of sesquiterpenes follows below.

\subsubsection{Peroxy radicals and glycolaldehyde as HCHO precursors}

Globally, methylperoxy radicals $\left(\mathrm{CH}_{3} \mathrm{O}_{2}\right)$, which are produced from the oxidation of $\mathrm{CH}_{4}$ and peroxyacetyl (PA) radicals, are an important precursor of HCHO (Fried et al., 1997; Sumner et al., 2001; Tuazon and Atkinson, 1990; Lee et al., 1998). The HCHO production mechansim via $\mathrm{CH}_{4}$ oxidation is described in detail by Fried et al. (1997). The lifetime of $\mathrm{CH}_{4}$ at $298 \mathrm{~K}$ with $6 \times 10^{6}$ molecule $\mathrm{cm}^{-3} \mathrm{OH}$ is $\sim 10$ months (Atkinson et al., 2006), and hence it is assumed that $\mathrm{CH}_{4}$ is homogeneously distributed throughout the boundary layer at a concentration of $1.774 \mathrm{ppm}$ (IPCC, 2007). Peroxyacetyl $\left(\mathrm{PA}, \mathrm{CH}_{3} \mathrm{C}(\mathrm{O}) \mathrm{O}_{2}\right)$ radicals are produced from $\mathrm{OH}$ initiated oxidation of $\mathrm{CH}_{3} \mathrm{CHO}$, MVK, MACR, and methylglyoxal $\left(\mathrm{CH}_{3} \mathrm{C}(\mathrm{O}) \mathrm{C}(\mathrm{O}) \mathrm{H}\right.$, MeGly), thermal decomposition of PAN, photolysis of MeGly and biacetyl (Atkinson et 
Table 3. Reaction rate constants $k$ and HCHO yield for ozonolysis of VOCs that are at least partially biogenic.

\begin{tabular}{|c|c|c|c|}
\hline & $\mathrm{k}\left(\mathrm{cm}^{3} \text { molecule }{ }^{-1} \mathrm{~s}^{-1}\right)^{\mathrm{b}}$ & HCHO yield ${ }^{c}$ & Reference \\
\hline $\mathrm{MBO}$ & $1.0 \times 10^{-17}$ & $0.47^{\mathrm{a}}$ & $\begin{array}{l}\text { Atkinson et al. }(2006)^{\mathrm{b}} ; \\
\text { Fantechi et al. }(1998)^{\mathrm{c}} ; \\
\text { Alvarado et al. }(1999)^{\mathrm{c}} ; \\
\text { Grosjean and Grosjean }(1995)^{\mathrm{c}}\end{array}$ \\
\hline Isoprene & $1.03 \times 10^{-14} \times \exp (-1995 / T)$ & 0.9 & $\begin{array}{l}\text { Atkinson et al. }(2006)^{\mathrm{b}} \\
\text { Grosjean et al. }(1993 \mathrm{a})^{\mathrm{c}}\end{array}$ \\
\hline$\alpha$-pinene & $6.3 \times 10^{-16} \times \exp (-580 / T)$ & 0.25 & $\begin{array}{l}\text { Atkinson et al. }(2006)^{\mathrm{b}} \text {; } \\
\text { Atkinson and Arey }(2003)^{\mathrm{b}} \text {; } \\
\text { Lee et al. }(2006 \mathrm{a})^{\mathrm{c}}\end{array}$ \\
\hline$\beta$-pinene & $1.5 \times 10^{-17}$ & 0.65 & $\begin{array}{l}\text { Atkinson and Arey }(2003)^{\mathrm{b}, \mathrm{c}} \text {; } \\
\text { Lee et al. }(2006 \mathrm{a})^{\mathrm{c}}\end{array}$ \\
\hline Myrcene & $4.76 \times 10^{-16}$ & 0.51 & $\begin{array}{l}\text { Atkinson and Arey }(2003)^{\mathrm{b}, \mathrm{c}} \text {; } \\
\text { Lee et al. }(2006 \mathrm{a})^{\mathrm{c}}\end{array}$ \\
\hline 3-carene & $3.61 \times 10^{-17}$ & 0.25 & $\begin{array}{l}\text { Atkinson and Arey }(2003)^{\mathrm{b}, \mathrm{c}} \text {; } \\
\text { Lee et al. }(2006 \mathrm{a})^{\mathrm{b}}\end{array}$ \\
\hline Terpinolene & $1.83 \times 10^{-15}$ & 0.29 & $\begin{array}{l}\text { Atkinson and Arey }(2003)^{\mathrm{b}, \mathrm{c}} \text {; } \\
\text { Lee et al. }(2006 \mathrm{a})^{\mathrm{b}}\end{array}$ \\
\hline Linalool & $4.33 \times 10^{-16}$ & 0.35 & $\begin{array}{l}\text { Atkinson and Arey }(2003)^{\mathrm{b}, \mathrm{c}} \text {; } \\
\text { Lee et al. }(2006 \mathrm{a})^{\mathrm{b}}\end{array}$ \\
\hline$\alpha$-terpinene & $2.38 \times 10^{-14}$ & 0.04 & $\begin{array}{l}\text { Atkinson and Arey }(2003)^{\mathrm{b}, \mathrm{c}} \text {; } \\
\text { Lee et al. }(2006 \mathrm{a})^{\mathrm{b}}\end{array}$ \\
\hline Limonene & $1.98 \times 10^{-16}$ & 0.15 & Atkinson and Arey $(2003)^{b, c}$ \\
\hline Methy chavicol & $1.2 \times 10^{-17}$ & 0.61 & $\begin{array}{l}\text { Bouvier-Brown et al. }(2009 a)^{b} \text {; } \\
\text { Lee et al. }(2006 a)^{c}\end{array}$ \\
\hline$\alpha$-humulene & $1.19 \times 10^{-14}$ & 0.035 & $\begin{array}{l}\text { Atkinson and Arey }(2003)^{\mathrm{b},} \\
\text { Lee et al. }(2006 \mathrm{a})^{\mathrm{c}}\end{array}$ \\
\hline$\beta$-caryophyllene & $1.19 \times 10^{-14}$ & 0.11 & $\begin{array}{l}\text { Atkinson and Arey }(2003)^{\mathrm{b}, \mathrm{c}} \text {; } \\
\text { Calogirou et al. }(1997)^{\mathrm{c}} \\
\text { Grosjean et al. }(1993 \mathrm{~b})^{\mathrm{c}}\end{array}$ \\
\hline Ethene & $9.1 \times 10^{-15} \times \exp (-2580 / T)$ & 1.03 & $\begin{array}{l}\text { Atkinson et al. }(2006)^{\mathrm{b}} \\
\text { Sumner et al. }(2001)^{\mathrm{c}}\end{array}$ \\
\hline Propene & $5.5 \times 10^{-15} \times \exp (-1880 / T)$ & 0.78 & $\begin{array}{l}\text { Atkinson et al. }(2006)^{\mathrm{b}} \text {; } \\
\text { Sumner et al. }(2001)^{\mathrm{c}}\end{array}$ \\
\hline
\end{tabular}

\footnotetext{
a Averaged HCHO yield (0.48, 0.57 with OH scavengers from Fantechi et al. (1999), 0.29 from Alvarado et al. (1999), and 0.36 from Grosjean and Grosjean, 1995).

b Reference for reaction constants.

${ }^{\mathrm{c}}$ Reference for $\mathrm{HCHO}$ yields.
}

al., 2006; Klotz et al., 2001; Koch and Moortgat, 1998; LaFranchi et al., 2009; Orlando et al., 1999; Tuazon and Atkinson, 1989). PA radicals are rapidly destroyed by reactions with $\mathrm{NO}, \mathrm{HO}_{2}$, and $\mathrm{RO}_{2}$ with a lifetime of $\sim 10 \mathrm{~s}$ under BEARPEX conditions (LaFranchi et al., 2009). Therefore, the steady-state concentration of PA radicals, $[\mathrm{PA}]_{\mathrm{ss}}$, can be estimated by Eq. (C3) as outlined in Appendix C. PA removal reactions produce $\mathrm{CH}_{3} \mathrm{CO}_{2}$ (Tyndall et al., 2001; Hasson et al., 2004; Jenkin et al., 2007), which, upon decomposition and reaction with $\mathrm{O}_{2}$ forms $\mathrm{CH}_{3} \mathrm{O}_{2}$ (Reactions R13-R15 in Appendix $\mathrm{C}$ ). We assume that $\mathrm{CH}_{3} \mathrm{O}_{2}$ is rapidly converted into $\mathrm{HCHO}$. The $\mathrm{HCHO}$ production from $\mathrm{CH}_{3} \mathrm{O}_{2}$ showed a strong diurnal pattern with a daytime peak both in the High and Low period due to diurnal distributions of $[\mathrm{PA}],[\mathrm{OH}]$, temperature, and light intensity (Eq. C4). The mean production rates in the High and Low period are $0.42 \pm 0.05$ and $0.17 \pm 0.08 \mathrm{ppb} \mathrm{h}^{-1}$ during the daytime, respectively, which are comparable in magnitude to the $\mathrm{OH}$-initiated production (Fig. 11).

Glycolaldehyde (GA) is known to be secondarily produced through the oxidation of ethene, MBO, isoprene and other VOCs (Butkovskaya et al., 2006; Magneron et al., 2005; Bacher et al., 2001). Although the HCHO yields used in Sect. 3.2.1 are expected to be incorporated into the net HCHO production assuming the experimentally obtained HCHO yields were corrected for by-product effects, Spaulding et al. (2003) found using multiple-regression and factor analysis that only about 30\% of GA at Blodgett Forest 


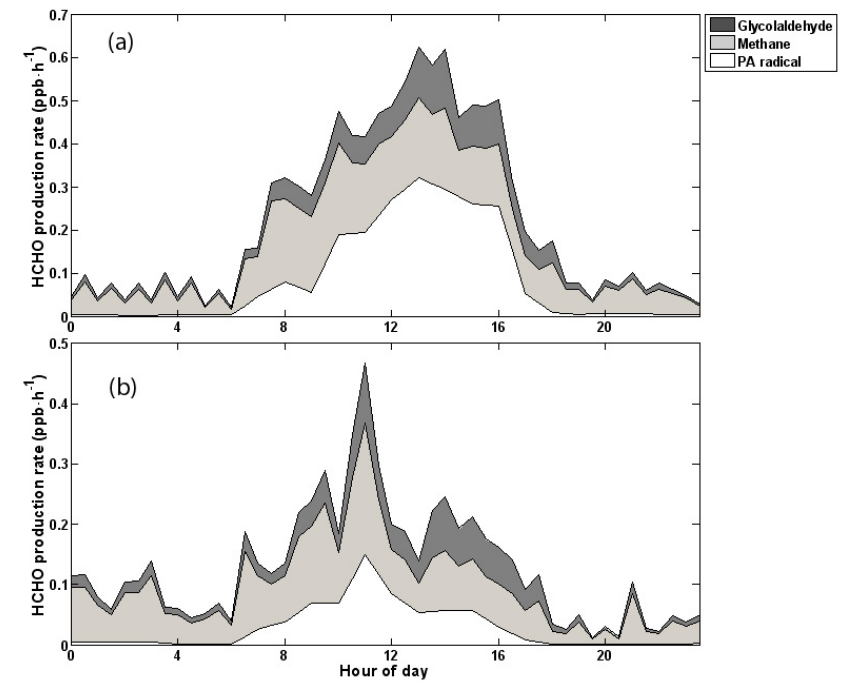

Fig. 11. Mean diurnal HCHO production rate $\left(\mathrm{ppbh}^{-1}\right)$ from $\mathrm{CH}_{3} \mathrm{O}_{2}$ radical, which is produced from $\mathrm{PA}$ (white), $\mathrm{CH}_{4}$ (light gray), and glycolaldehyde (dark gray) during (a) the High and (b) Low HCHO period.

is attributable to biogenic sources. Thus, GA effects on $\mathrm{HCHO}$ production are worthy of consideration. Unfortunately, GA was not observed during the BEAPREX period, so we use the diurnal profile of GA measured by Spaulding et al. for day $258 \sim 259$, which is the same period of year as that of $\mathrm{HCHO}$ measurements. The mean $\mathrm{HCHO}$ yield of 0.72 was used for $\mathrm{GA}+\mathrm{OH}$ reaction (Butkovskaya et al., 2006; Magneron et al., 2005) and 0.59 for photolysis (Magneron et al., 2005; Bacher et al., 2001). The rate constant of $1.1 \times 10^{-11} \mathrm{~cm}^{3} \mathrm{molec}^{-1} \mathrm{~s}^{-1}$ was used for $\mathrm{OH}+\mathrm{GA}$ reaction and $j_{\mathrm{GA}}$ was scaled with PAR using TUV model (A5). The mean estimated HCHO production rate from GA during daytime $(10: 00 \sim 16: 00)$ is $0.09 \pm 0.02 \mathrm{ppbh}^{-1}$ and $0.06 \pm 0.02 \mathrm{ppb} \mathrm{h}^{-1}$ in the High and Low phase, respectively (Fig. 11).

\section{Estimated HCHO constrained by observed production and loss rates}

To evaluate in-situ chemical processes based on known $\mathrm{HCHO}$ production and loss mechanisms, $\mathrm{HCHO}$ concentrations were calculated from an integration of the budget equation as shown in Eq. (4). $P_{\mathrm{HCHO}}$ is the total production rate from observed BVOCs (17 BVOCs from $\mathrm{OH}$-initiated oxidation, 13 BVOCs from Ozonolysis, $\mathrm{CH}_{3} \mathrm{O}_{2}$ radical from PA radical and $\mathrm{CH}_{4}$ oxidation, and glycolaldehyde). $L_{\mathrm{HCHO}}$ is the sum of the 1st order reaction rate constants from photolysis scaled to the PAR observations by the TUV model, reaction with observed $\mathrm{OH}$, and estimated dry deposition. $A$ represents advection by the mean wind. The calculation was performed every $30 \mathrm{~min}$ from 10:00 initialized with the ob-

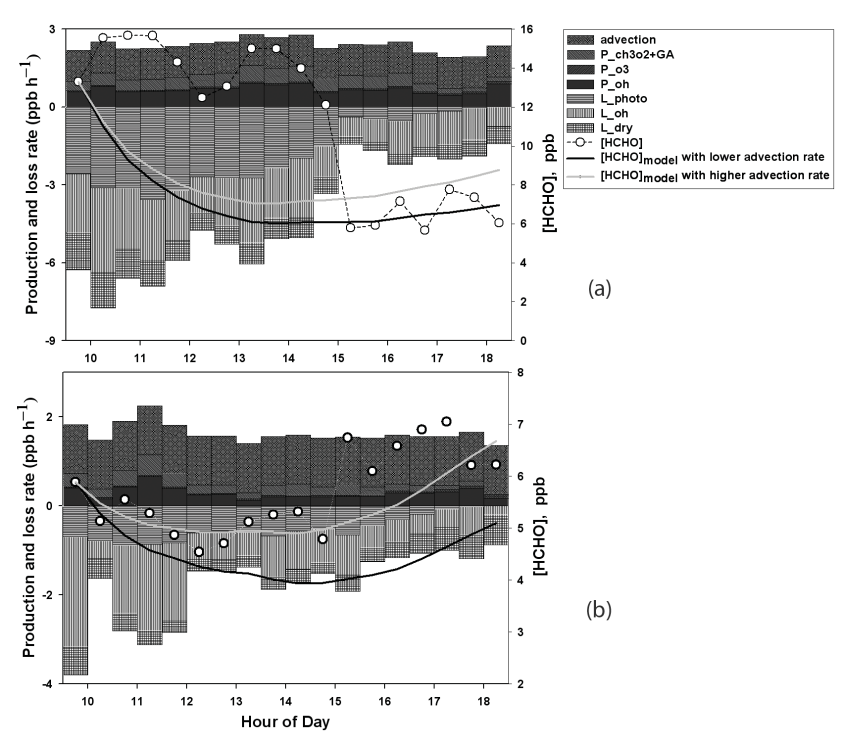

Fig. 12. Total mean daytime production and loss rates (left y-axis) and the concentrations (right y-axis) of $\mathrm{HCHO}$ (a) for the High and (b) Low HCHO period. Bar plots denote production and loss rates estimated from the observations ( $\mathrm{P}$ : production, L: loss, and subscripts represent reaction pathways such as oh: by $\mathrm{OH}, \mathrm{o3}$ : by ozone, ch3o2 + GA: from methyl peroxy radical and glycolaldehyde, photo: by photolysis, and dry: by dry deposition). White circles with dotted line denote the observed $[\mathrm{HCHO}]_{\text {obs }}$. Thick gray and black lines show the calculated $[\mathrm{HCHO}]_{\text {model }}$ using a time dependent integration of the mean $\mathrm{HCHO}$ production and loss rates initialized by $[\mathrm{HCHO}]_{\mathrm{obs}}$ at 09:30 with a constant advection rate of 0.7 and $1.2 \mathrm{ppbh}^{-1}$, respectively.

served [HCHO $]_{09: 30}$ to avoid large, unconstrained effects of entrainment during the rapid growth phase of the morning boundary layer (e.g., fumigation), and thereafter the preceding result was used as $[\mathrm{HCHO}]_{t-1}$ for the next step's calculation. According to sonde measurements conducted in BEARPEX 2007 and 2009 (Choi et al., 2010), the atmospheric boundary layer (ABL) is already well developed by that time, and thus the growth in boundary layer height is not expected to significantly affect $\mathrm{HCHO}$ levels directly for the interval under consideration.

$\left[\mathrm{HCHO}_{t}=[\mathrm{HCHO}]_{t-1}+\int_{t-1}^{t}\right.$
$\left(P_{\mathrm{HCHO}}+A-L_{\mathrm{HCHO}} \cdot[\mathrm{HCHO}]_{t-1}\right) d t$

Advection is one of the most vexing uncertainties in most atmospheric chemistry studies, especially when moderately reactive secondary products are concerned like HCHO or other OVOCs. The oak forests located approximately $30 \mathrm{~km}$ upwind from the observation site are hearty emitters of isoprene, and are expected to affect the HCHO budget at Blodgett Forest. Therefore, advection from sources upwind (most notably the oak forests of the foothills) may be much more important than local photochemistry. To set the upper limit 
of the advection, we first focus on the mean diurnal pattern of the observed $\mathrm{HCHO}$ for the Low phase, which appears similar to other species whose levels at Blodgett are controlled by advection, such as ozone, $\mathrm{NO}_{\mathrm{x}}$, and isoprene as discussed earlier (Figs. 7 and 8). If we assume the discrepancies between modelled and observed [HCHO] are solely the result of advection, ignoring additional sources of $\mathrm{HCHO}$ in the Low period, an upper-limit to the background advection rate can be estimated. Figure 12(b) shows the daytime rise of observed [HCHO] corresponds fairly well with the model results using $A=1.2 \mathrm{ppbh}^{-1}$. The advection rate may also be independently estimated from the horizontal gradient of HCHO evaluated using model results and/or satellite data, and the mean wind. Photochemical modelling of California's central valley performed for the summer daytime conditions of 2000 by Steiner et al. (2007) indicates the potential for formaldehyde gradients to exist in the transect from Sacramento to Blodgett. The largest gradients observed in the vicinity of Blodgett forest (see their Fig. 3), irrespective of exact orientation, appears to be about $0.04 \mathrm{ppb} / \mathrm{km}$. Similar estimates of the regional gradients can be made using satellite data from the Ozone Monitoring Instrument as shown in Millet et al. (2008). Assuming that $\sim 80 \%$ of the $\mathrm{HCHO}$ column resides in the ABL in regions with strong surface sources (Martin et al., 2004), broad summertime horizontal gradients can be seen that range from $0.015-0.04 \mathrm{ppb} / \mathrm{km}$. While the daytime surface winds average below $3 \mathrm{~m} / \mathrm{s}$, mixed layer winds above Blodgett Forest are known to be somewhat higher - from 3 to $5 \mathrm{~m} / \mathrm{s}$ (Choi et al., 2010). A very liberal estimate of daytime $\mathrm{HCHO}$ advection rates, then, can be made ranging from $0.2-0.7 \mathrm{pph}^{-1}$. We thus used $0.7-1.2 \mathrm{ppbh}^{-1}$ as the largest conceivable advection rates for the time dependent $[\mathrm{HCHO}]$ calculation in Eq. (4).

The principal terms of the HCHO budget are summarized as a diurnal mean pattern in Fig. 12, which clearly shows the losses (linearly dependent on the observed HCHO) outpacing the known sources steadily throughout the day (10:00 16:00) particularly for the High period. Modelled concentrations of $\mathrm{HCHO},[\mathrm{HCHO}]_{\text {model }}$, showed significant discrepancies with observed levels, $[\mathrm{HCHO}]_{\mathrm{obs}}$, implying that there are large sources not considered in the analysis of the measured VOCs, especially during the High phase. $[\mathrm{HCHO}]_{\text {model }}$ decreases rapidly in the beginning of the calculation due to loss rates in great excess over observed production terms, and levels off in about $3 \mathrm{~h}$ where production and loss rates are roughly balanced to yield $6 \sim 8 \mathrm{ppb}$ of $\mathrm{HCHO}$. The modelled concentration only starts to rise significantly after $\sim$ 15:00 when the photochemical loss terms are fading and the (constant) advection begins to outpace them. Although the large advection estimate is clearly not enough to fully explain the overabundance observed at the site during midday, it does capture the feature of gradual late afternoon build-up in $[\mathrm{HCHO}]_{\mathrm{obs}}$.

Further investigation of other trace gases that originate upwind can provide insight into the importance of
$\mathrm{HCHO}$ advection. Isoprene oxidation products, MVK and methacrolein, are expected to peak in the midday if the local isoprene emission is important because their concentrations strongly depend on the $\mathrm{OH}$ level and isoprene emission, which depends on leaf temperature and photon flux density incident on the leaf (Monson and Fall, 1989). However, isoprene and methacrolein at Blodgett build up continuously to the early evening in both High and Low phases (Fig. 7c and d), implying that the late afternoon increase is caused by advection from the upwind oak forests of the foothills. Anthropogenic VOCs, such as benzene and toluene, which are transported from upwind urban areas show a similar late afternoon or early evening peak around 18:00 20:00 (Fig. 7f). Ozone also displays this characteristic rise throughout the day as photochemical precursors (anthropogenic VOCs and $\mathrm{NO}_{\mathrm{x}}$ as well as biogenic isoprene) and their products advect to the site (Fig. 7e). Taken in sum, the late afternoon increase in $[\mathrm{HCHO}]_{\text {model }}$ and in $[\mathrm{HCHO}]_{\text {obs }}$ of the Low period, as well as the secondary maximum in $[\mathrm{HCHO}]_{\text {obs }}$ seen in the High period from 16:00-20:00 (Fig. 6a) can likely be explained in large part by advection from the upwind oak forest and/or urban sources of HCHO and its precursors. However, advection is unlikely to explain the $\mathrm{HCHO}$ maxima reached during the peak in photochemical activity of the High period.

We note that $[\mathrm{HCHO}]_{\mathrm{obs}}$ in the High phase has a pattern similar to the chemical species controlled by local, fast photochemistry, such as $\mathrm{OH}$ and $\mathrm{HO}_{2}$ (Figs. $7 \mathrm{~g}$ and h). In addition, local $\mathrm{OH}$-initiated $\mathrm{HCHO}$ production significantly decreased in the Low phase along with $[\mathrm{HCHO}]_{\text {obs }}$ due to the decrease in concentrations both of BVOCs and $\mathrm{OH}$, implying midday HCHO in the High phase was strongly influenced by local photochemistry. According to Holzinger et al. (2005), the concentrations of oxidation products from VR-BVOCs emitted from the pine forest at Blodgett rapidly increase at sunrise, peak between 10:00 15:00 and steadily decrease in the late afternoon with a smaller secondary peak around 20:00. These diurnal patterns may also imply that the oxidation of unidentified BVOCs play an important role in $\mathrm{HCHO}$ production during midday, because of their similarity to the High phase $\mathrm{HCHO}$ profile and the fact that the oxidation of most reactive BVOCs will produce HCHO. Kurpius and Goldstein (2003) showed that half of the measured canopy ozone flux in the summer is believed to be due to an additional chemical sink; namely, the reactions of VR-BVOCs with ozone, supporting the possible existence of undetected VR-BVOCs purported by Holzinger et al. (2005) and further evinced in the present HCHO study.

\section{Possible missing HCHO sources}

The analysis presented so far clearly indicates that there may be other, more significant sources of HCHO during midday in the High period at Blodgett, where isoprene is not the dominant BVOC. Bouvier-Brown et al. (2009b) showed 
significant levels of sesquiterpene emissions that mostly react before escaping the forest canopy from branch enclosure experiments, supporting this argument. In addition, Farmer and Cohen (2008) argued that vigorous intra-canopy chemistry was evident at this site based on estimates of vertical gradients and fluxes of $\Sigma$ ANs, $\Sigma$ PNs, $\mathrm{NO}_{2}$ and $\mathrm{HNO}_{3}$. Wolfe et al. (2009) also supported that hypothesis based on the relatively larger downward flux of PPN compared to those of MPAN and PAN. All of these findings support rapid production of oxidized VOCs, likely including HCHO, within or just above the canopy. In what follows, we assume that the discrepancies between $[\mathrm{HCHO}]_{\text {model }}$ and $[\mathrm{HCHO}]_{\text {obs }}$ shown in Fig. 12(a) result from missing local source terms. The contribution of missing sources can be estimated by adding a new term, $P_{\text {missing }}$ to Eq. (4), and by forcing $[\mathrm{HCHO}]_{\text {model }}$ to match $[\mathrm{HCHO}]_{\text {obs }}$ over several hours. The average $P_{\text {missing }}$ magnitude during daytime (10:00 15:00) was $1.1 \sim 1.6 \mathrm{ppb} \mathrm{h}^{-1}$ in the High phase. In order to explain this missing source term, we examine, in more detail, the validity of some of the major production terms currently in the model.

As noted above, BVOC sources of $\mathrm{HCHO}$ from ozone or $\mathrm{OH}$ reactions may be underestimated. Bouvier-Brown et al. (2009a) reported that total sesquiterpenes measured at $1.5 \mathrm{~m}$ above the forest floor showed a large discrepancy with branch enclosure measurements, implying that about $90 \%$ of the measured reactive compounds disappear through oxidation shortly after they are emitted into the sub-canopy atmosphere. Considering that all monoterpene and sesquiterpene data were obtained at $9.3 \mathrm{~m}$ and other BVOCs obtained at least $6.4 \mathrm{~m}$ above the ground, the possibility remains that ozonolysis of BVOCs, too reactive to be detected at those levels, could contribute significantly to the overall HCHO. With the assumption that the discrepancies in sesquiterpene concentrations between branch enclosures and tower measurements are caused by a rapid chemical loss, and that $\mathrm{HCHO}$ is produced through the oxidation processes with a yield of $10 \sim 50 \%$, analogous to the analysis of BouvierBrown et al. (2009a), the ozonolysis of sesquiterpenes could contribute approximately 0.2 to $0.9 \mathrm{ppb} \mathrm{h}^{-1}$ to the $\mathrm{HCHO}$ production rate near the branches. This result is a lower limit because some compounds such as $\beta$-caryophyllene, which was one of the major emissions from manzanita (BouvierBrown et al., 2009b), were not taken into account due to their high reactivity (Bouvier-Brown et al., 2009a). Furthermore, their estimates were derived all together for both the High and Low periods of HCHO measurements and are likely greater still during the High phase.

Similarly, Holzinger et al. (2005) estimated that 13 $66 \mu \mathrm{mol} \mathrm{m} \mathrm{m}^{-2} \mathrm{~h}^{-1}$ of unknown VR-BVOCs is emitted at Blodgett Forest during the summer and rapidly oxidized within $1 \mathrm{~min}$ just above the canopy during daytime. Because their lifetime is short enough to assume steady state at midday, the expected [VR-BVOCs] can be estimated using Eq. (5), which assumes that most VR-BVOCs are oxidized within a canopy height scale, and thus their flux aloft is negligible (this does not appear unrealistic considering their very short lifetime and the vertical distributions of their oxidation products).

$[\mathrm{VR}-\mathrm{BVOCs}]=\frac{F_{\mathrm{net}}}{z} \times \tau_{\mathrm{VR}-\mathrm{BVOCs}}$

$F_{\text {net }}$ is the net flux of VR-BVOCs $\left(13 \sim 66 \mu \mathrm{mol} \mathrm{m} \mathrm{m}^{-2}\right.$ $\left.\mathrm{h}^{-1}\right), z$ is the vertical length scale $(12 \mathrm{~m})$, and $\tau$ is the chemical lifetime of VR-BVOCs. The estimated HCHO production rate with a HCHO yield of $10 \%$ from VR-BVOC oxidation within the canopy is $2.1 \sim 10.8 \mathrm{ppb} \mathrm{h}^{-1}$. We also note that the diurnal profile of the oxidation products of VR-BVOCs showed a strong daytime peak, which is consistent with that of HCHO during the High phase, implying VR-BVOC oxiation may be an additional missing source of HCHO.

Perhaps more confounding than all of the above are recent indications that our understanding of $\mathrm{HO}_{\mathrm{x}}$ cycling in low- $\mathrm{NO}_{\mathrm{x}}$, high-VOC environments is poor. In one of the first indications of this problem, Thornton et al. (2002) proposed that $\mathrm{RO}_{2}+\mathrm{HO}_{2}$ reactions must be an inefficient sink of $\mathrm{HO}_{\mathrm{x}}$ in order for $\mathrm{HO}_{\mathrm{x}}$ loss to match known $\mathrm{HO}_{\mathrm{x}}$ sources and to explain observationally constrained ozone production rates obtained during the 1999 Southern Oxidant Study in Nashville, Tennessee. In this region, where isoprene was a dominant $\mathrm{RO}_{2}$ source, they suggested that the majority of $\mathrm{RO}_{2}+\mathrm{HO}_{2}$ reactions resulted in $\mathrm{HO}_{\mathrm{x}}$ recycling rather than termination via: $\mathrm{RO}_{2}+\mathrm{HO}_{2} \rightarrow \mathrm{RO}+\mathrm{OH}+\mathrm{O}_{2}$ or rapid photolysis of $\mathrm{ROOH}$, the supposed major product of $\mathrm{RO}_{2}+\mathrm{HO}_{2}$ reactions. Similar conclusions were reached by Lelieveld et al. (2008) in explaining the discrepancies between models and aircraft measurements made over tropical forests. LaFranchi et al. (2009) suggested high $\mathrm{RO}_{2} / \mathrm{HO}_{2}$ ratios (4 to 6) in the PAN analysis at Blodgett given the measured $\mathrm{OH}$ reactivity and photostationary state estimates of NO. In addition, modeled $\mathrm{OH}$ at Blodgett was significantly lower than observed, whereas $\mathrm{HO}_{2}$ showed reasonable agreement (Mao et al., 2009). Such situations are similar to those where enhanced $\mathrm{OH}$ recycling is required and high $\mathrm{RO}_{2} / \mathrm{HO}_{2}$ ratios are expected (Stevens et al., 1997; Hofzumahaus et al., 2009; Steiner et al., 2008; Tan et al., 2001). We assumed $\mathrm{RO}_{2} \sim \mathrm{HO}_{2}$, thus our source of $\mathrm{HCHO}$ from $\mathrm{RO}_{2}$ chemistry is potentially underestimated. In addition, the increased flux through alkoxy radicals implied by these suggestions could provide another HCHO source not contained in our model. Wolfe et al. (2010) also show similar discrepancies in $\mathrm{HO}_{\mathrm{x}}$ budget to Mao et al. (2008) and suggested that PA production may be $30 \%$ greater than LaFranchi et al. (2009) from extra PA sources with model simulations using the master chemical mechanism (MCM).

Moreover, a recent $\mathrm{HO}_{\mathrm{x}}$ study downwind of the urban region of the Pearl River Delta in China (Hofzumahaus et al., 2009) suggested the need for additional recycling of $\mathrm{RO}_{2}$ to $\mathrm{OH}$ that does not alter the $\mathrm{HO}_{2}$ and $\mathrm{O}_{3}$ levels. As the most 
simple case, Hofzumahaus et al. (2009) suggested the existence of a new reactant or suite of reactants, $\mathrm{X}$, that react with both $\mathrm{RO}_{2}$ and $\mathrm{HO}_{2}$ at a similar rate, like $\mathrm{NO}$, but without net production of ozone. If such reactions, regardless of the number of reactants, produce $\mathrm{HCHO}$ as a secondary product as the $\mathrm{RO}_{2}+\mathrm{NO}$ reactions do, then enhanced $\mathrm{RO}_{2} / \mathrm{HO}_{2}$ ratios might also contribute to the requisite missing sources of $\mathrm{HCHO}$ at Blodgett without drastically modifying the observed $\mathrm{O}_{3}$ and $\mathrm{NO}$.

Consequently, we conclude from the above discussion that the elevated levels of $\mathrm{HCHO}$ observed during the High phase of the experiment are consistent with the hypothesis of Holzinger et al. (2005) and the sesquiterpene emission measurements of Bouvier-Brown et al. (2009a, b); namely, that highly reactive VOCs emitted from the pine forest at Blodgett are being rapidly oxidized before escaping the canopy. However, a detailed mechanistic description and identification of the VOC and oxidants $\left(\mathrm{O}_{3}\right.$ and/or $\left.\mathrm{OH}\right)$ responsible for the anomalously high $\mathrm{HCHO}$ remains elusive. Clearly eddy covariance flux measurements of $\mathrm{HCHO}$ above this or similar forests would provide a key test of our extention of the Holzinger hypothesis. Underlying this large, local photochemical HCHO source, is a more modest advective component from the Sacramento plume and forests of the foothills that appears more dominant in the Low phase.

\section{Appendix A}

\section{Estimate of photolysis rate constants}

All photolysis rate constants used in this study were estimated from the TUV model v4.5 (NCAR, 2008). During the BEARPEX 2007 intensive observational period, the TUV model yields strong relationships between PAR and $j_{\mathrm{NO}_{2}}, j_{1 a}, j_{1 b}, j_{9}$ (in Appendix C), and $j_{\mathrm{GA}}$, which are based on a least-squares polynomial fit, under several different conditions (cloud optical depth (COD) 0 and aerosol optical depth (AOD) 0.235; COD 0.5 and AOD 0.235; COD 0 and AOD 0.5; COD 0.5 and AOD 0.5) with $R^{2}=0.998,1.000$, $0.999,0.999$, and 0.999 respectively as shown in Eq. (A1) to Eq. (A5).

$$
\begin{aligned}
& j_{\mathrm{NO}_{2}}\left(s^{-1}\right)=-3.68 \times 10^{-13}(\mathrm{PAR})^{3}-8.15 \times 10^{-11}(\mathrm{PAR})^{2} \\
&+5.91 \times 10^{-6}(\mathrm{PAR})-1.03 \times 10^{-5} \\
& j_{1 a}\left(s^{-1}\right)=-2.67 \times 10^{-15}(\mathrm{PAR})^{3}+9.65 \times 10^{-12}(\mathrm{PAR})^{2} \\
&+ 6.47 \times 10^{-8}(\mathrm{PAR})-1.25 \times 10^{-8} \\
& j_{1 b}\left(s^{-1}\right)=-3.25 \times 10^{-15}(\mathrm{PAR})^{3}+8.12 \times 10^{-12}(\mathrm{PAR})^{2} \\
&+1.90 \times 10^{-8}(\mathrm{PAR})-1.37 \times 10^{-8} \\
& j_{9}\left(s^{-1}\right)= 5.7 \times 10^{-18}(\mathrm{PAR})^{4}-2.4 \times 10^{-14}(\mathrm{PAR})^{3} \\
&+2.6 \times 10^{-11}(\mathrm{PAR})^{2}+6.0 \times 10^{-8}(\mathrm{PAR})+8.5 \times 10^{-8}
\end{aligned}
$$

$$
\begin{aligned}
j_{\mathrm{GA}}\left(s^{-1}\right)= & -3.57 \times 10^{-16}(\mathrm{PAR})^{3}+1.73 \times 10^{-12}(\mathrm{PAR})^{2} \\
& +5.20 \times 10^{-10}(\mathrm{PAR})
\end{aligned}
$$

\section{Appendix B}

\section{$\mathrm{HO}_{2}$ and $\mathrm{NO}_{3}$ as a $\mathrm{HCHO}$ sink}

Observed $\mathrm{HO}_{2}$ at Blodgett is big enough to make $\mathrm{HO}_{2}+\mathrm{HCHO}$ Reaction (R1 in Appendix B) significant compared to $\mathrm{OH}+\mathrm{HCHO}$ reaction. However, the reverse thermal decomposition is also very fast under the low- $\mathrm{NO}_{\mathrm{x}}$ conditions with the rate constant, $k_{-1}=2.4 \times 10^{12} \mathrm{e}^{(-7000 / T)}$ (Atkinson et al., 2006). Provided that thermal decomposition of $\mathrm{HOCH}_{2} \mathrm{OO}\left(0.68 \times 10^{2} \mathrm{~s}^{-1}\right.$ at $\left.15^{\circ} \mathrm{C}\right)$ is much faster than other reactions of the adduct, we can assume that Reaction R1 in Appendix B reaches equilibrium within a very short time $(\sim 15 \mathrm{~ms})$ with its equilibrium constant of $\mathrm{K}_{1}=$ $1.3 \times 10^{-15} \mathrm{~cm}^{3} \mathrm{molec}^{-1}$ at $15^{\circ} \mathrm{C}$ (Atkinson et al., 2006). $\mathrm{HOCH} \mathrm{H}_{2} \mathrm{OO}$ also reacts with $\mathrm{NO}, \mathrm{HO}_{2}$, or $\mathrm{RO}_{2}$, through which $\mathrm{HCHO}$ can be removed in the atmosphere instead of being regenerated from thermal dissociation. Therefore, at equilibrium of Reaction (R1 in Appendix B), the net $\mathrm{HCHO}$ loss rate can be expressed as

$$
k_{\text {net }}=K_{1}\left[\mathrm{HO}_{2}\right] \times\left(k_{\mathrm{HOCH}_{2} \mathrm{O}_{2}}\left[\mathrm{HO}_{2}\right]+k_{\mathrm{HOCH}_{2} \mathrm{O}_{2}}\left[\mathrm{RO}_{2}\right]+k_{\mathrm{HOCH}_{2} \mathrm{O}_{2}}[\mathrm{NO}]\right)
$$

Although it can be an important $\mathrm{HCHO}$ loss under very low temperature conditions $(T \leq 210 \mathrm{~K})$ typical of the tropopause (Hermans et al., 2005), the net HCHO loss rate by $\mathrm{HO}_{2}$ estimated at Blodgett Forest is only $9.1 \times 10^{-9} \mathrm{~s}^{-1}$ with observed $\mathrm{HCHO}$ and $\mathrm{HO}_{2}$, and estimated $[\mathrm{NO}]_{\mathrm{ss}}$ and $\left[\mathrm{RO}_{2}\right]$, which is 4 orders of magnitude smaller than the HCHO loss by $\mathrm{OH}$ during daytime. Therefore, we conclude that $\mathrm{HO}_{2}$ initiated HCHO removal processes within the boundary layer is negligible.

$\mathrm{HCHO}$ removal process due to $\mathrm{NO}_{3}$ (Reaction $\mathrm{R} 2$ in Appendix B) was about 450 times slower than that from $\mathrm{OH}$ oxidation even at night when $\left[\mathrm{NO}_{3}\right]=3$ ppt was assumed (Hurst et al., 2001), and the nitrate at Blodgett is believed to be far less (R. Cohen, unpublished data). Thus, we also concluded that $\mathrm{NO}_{3}$ does not play an important role in nighttime $\mathrm{HCHO}$ loss mechanisms compared to $\mathrm{OH}$ in Blodgett forest.

$$
\begin{aligned}
& \mathrm{HCHO}+\mathrm{HO}_{2} \longleftrightarrow \mathrm{HOCH}_{2} \mathrm{OO} \\
& \mathrm{HCHO}+\mathrm{NO}_{3} \longrightarrow \mathrm{HNO}_{3}+\mathrm{HCO}
\end{aligned}
$$




\section{Appendix C}

\section{HCHO production pathways}

\section{C1 HCHO yield from $\mathrm{OH}$-initiated isoprene oxidation}

The HCHO yield from isoprene oxidation is relatively well understood compared to other biogenic VOCs (Sumner et al., 2001; Dreyfus et al., 2002; Paulot et al., 2009). Isoprene (Isop) is attacked by $\mathrm{OH}$ to form isoprene peroxy radical (Isop- $\mathrm{O}_{2}$ ). Isop- $\mathrm{O}_{2}$ then reacts with $\mathrm{NO}$ to produce Isop-O radical with the yield of $90 \%$ (Reaction R2a in Appendix C) and subsequently to produce HCHO, MVK, and MACR (Reactions R5a, b in Appendix C) with a yield of $63 \%, 35 \%$, and $24 \%$, respectively, in high- $\mathrm{NO}_{\mathrm{x}}$ conditions (Tuazon and Atkinson, 1990; Paulson et al., 1992; Ruppert and Becker, 2000; Paulot et al., 2009; Miyoshi et al., 1994; Sprengnether et al., 2002; Karl et al., 2006). On the other hand, Isop- $\mathrm{O}_{2}$ also competitively reacts with $\mathrm{RO}_{2}$ to produce $\mathrm{HCHO}$, MVK, and MACR with a yield of $34 \%$, $16 \%$, and 20\%, respectively, via Isop-O (Reaction R4a in Appendix C) under $\mathrm{NO}_{\mathrm{x}}$-free conditions (Ruppert and Becker, 2000; Miyoshi et al., 1994). Recent isoprene photooxidation studies proposed that $\mathrm{HCHO}$ can be secondarily produced from isoprene nitrates, which are products of the Isop $+\mathrm{OH}$ reaction under high-NOx conditions (Paulot et al., 2009). However, considering a low yield of isoprene nitrates $(11.7 \%)$ and assuming that the chamber experimental results already reflect $\mathrm{HCHO}$ yield from the further reaction of Isop- $\mathrm{ONO}_{2}+\mathrm{OH}$, we do not consider this new finding in this calculation. Consequently, assuming that the $\mathrm{HCHO}$ yield from isoprene oxidation responds linearly to the relative abundance of $\mathrm{NO}$, we can define a $\mathrm{HCHO}$ yield of $\mathrm{OH}$-initiated isoprene oxidation as Eqs. ( $\mathrm{C} 1$ and $\mathrm{C} 2)$, where $k_{2}=0.9 \times 10^{-11}$ (Stevens et al., 1999), $k_{3}=1.6 \times 10^{-11}$, and $k_{4}=4.0 \times 10^{-12} \mathrm{~cm}^{3} \mathrm{molec}^{-1} \mathrm{~s}^{-1}$ at room temperature (Jenkin et al., 1998), and $\left[\mathrm{RO}_{2}\right]=\left[\mathrm{HO}_{2}\right]$ is assumed in order to obtain $\beta$ (Sumner et al., 2001; Dreyfus et al., 2002).

Isop $+\mathrm{OHO}_{2} \stackrel{\text { Isop-O }}{\longrightarrow} 2+\mathrm{H}_{2} \mathrm{O}$

$$
\begin{aligned}
\text { Isop }-\mathrm{O}_{2}+\mathrm{NO} & \longrightarrow \text { Isop }-\mathrm{O}+\mathrm{NO}_{2}(90 \%) \\
& \longrightarrow \text { Isop }-\mathrm{ONO}_{2}(10 \%)
\end{aligned}
$$

$$
\text { Isop }-\mathrm{O}_{2}+\mathrm{HO}_{2} \longrightarrow \text { Isop }-\mathrm{OOH}+\mathrm{O}_{2}
$$

$$
\begin{array}{r}
\text { Isop }-\mathrm{O}_{2}+\mathrm{RO}_{2} \longrightarrow \text { Isop }-\mathrm{O}+\mathrm{RO}+\mathrm{O}_{2}(75 \%) \\
\longrightarrow \text { Isop }-\mathrm{OH}+\text { carbonyl }+\mathrm{O}_{2}(25 \%)
\end{array}
$$

$$
\begin{aligned}
\text { Isop }-\mathrm{O}+\mathrm{O}_{2} & \longrightarrow \mathrm{MVK}+\mathrm{HCHO}+\mathrm{HO}_{2} \\
& \longrightarrow \mathrm{MACR}+\mathrm{HCHO}+\mathrm{HO}_{2} \\
& \longrightarrow \text { products }+\mathrm{HO}_{2}
\end{aligned}
$$

Depending on $[\mathrm{NO}],\left[\mathrm{RO}_{2}\right]$, and $\left[\mathrm{HO}_{2}\right]$, the $\mathrm{HCHO}$ yield varied from 0.51 to 0.58 during the experiment. Therefore, we used the averaged value of 0.55 for the calculation of $\mathrm{HCHO}$ production rate from $\mathrm{OH}-i n i t i a t e d$ isoprene oxidation.

HCHO Yield, $\gamma=0.63 \beta+0.34(1-\beta)$

$\beta=\frac{k_{2}[\mathrm{NO}]}{k_{2}[\mathrm{NO}]+k_{3}\left[\mathrm{HO}_{2}\right]+k_{4}\left[\mathrm{RO}_{2}\right]}$

\section{$\mathrm{C2} \mathrm{HCHO}$ production from $\mathrm{CH}_{3} \mathrm{O}_{2}$ radical}

Major pathways leading to PA radical at Blodgett Forest were investigated by LaFranchi et al. (2009), including $\mathrm{OH}-$ initiated oxidation of $\mathrm{CH}_{3} \mathrm{CHO}$, MVK, MACR, and methylglyoxal $\left(\mathrm{CH}_{3} \mathrm{C}(\mathrm{O}) \mathrm{C}(\mathrm{O}) \mathrm{H}\right.$, MeGly), thermal decomposition of PAN, and photolysis of MeGly and biacetyl (Atkinson et al., 1999; Baeza-Romero et al., 2007; Klotz et al., 2001; Koch and Moortgat, 1998; Orlando et al., 1999; Tuazon and Atkinson, 1989), as shown in Reactions (R6-R12 in Appendix C). A previous study at Blodgett Forest reported that [MeGly] to [glyoxal] is $~ 3.4$ during daytime (Spaulding et al., 2003). Thus, we assumed daytime [MeGly] = $3.4 \times$ [glyoxal] in this discussion, with nighttime background values of $30 \mathrm{ppt}$ (LaFranchi et al., 2009; Spaulding et al., 2003). OH-initiated oxidation of MACR produces methacryloyl peroxy nitrate (MPAN) through the reversible reaction between methacryloyl peroxy radical $\left(\mathrm{MACO}_{3}\right)$ and $\mathrm{NO}_{2}$ (Orlando et al., 1999). The competing reaction of $\mathrm{MACO}_{3}$ with NO produces PA radical with the yield of 0.35 through the 1-methylvinyl radical $+\mathrm{O}_{2}$ addcut Reaction (R11 in Appendix $\mathrm{C})$. $\left[\mathrm{MACO}_{3}\right]$ was calculated following Lafranchi et al.'s (2009) Eq. (2) and rate constants in their Table 1. The detailed production pathways of PA radical are thoroughly described by LaFranchi et al. (2009). PA radical is destroyed rapidly by reactions with $\mathrm{NO}, \mathrm{HO}_{2}$, and $\mathrm{RO}_{2}$ with a lifetime of $\sim 10$ s (LaFranchi et al., 2009), and therefore, the concentration of PA radical, $[\mathrm{PA}]_{\mathrm{ss}}$, at steady state can be estimated from Eq. (C3), where $k_{6}=4.4 \times 10^{-12} \times e^{365 / T}$, $k_{7}=2.6 \times 10^{-12} \times e^{610 / T}, k_{10}=1.8 \times 10^{-12} \times e^{560 / T}$ (Atkinson et al., 2006), $k_{8}=1.9 \times 10^{-3} \times e^{-12,175 / T}[\mathrm{M}]\left(k_{0}\right)$ and $2.8 \times 10^{16} \times e^{-13,580 / T}\left(k_{\infty}\right)$ with $F_{\mathrm{c}}=0.6, k_{8}=8.5 \times$ $10^{-29}(T / 298)^{-6.5}[\mathrm{M}]\left(k_{0}\right)$ and $1.1 \times 10^{-11}(T / 298)^{-1.0}$ $\left(k_{\infty}\right)$ with $F_{\mathrm{c}}=0.6, k_{13}=8.1 \times 10^{-12} \times e^{270 / T}, k_{14}=4.3 \times$ $10^{-13} \times e^{1,040 / T}$, and $k_{15}=2.0 \times 10^{-12} \times e^{500 / T}$ (Tyndall et al., 2001).

$\mathrm{CH}_{3} \mathrm{CHO}+\mathrm{OH} \longrightarrow \mathrm{PA}+\mathrm{H}_{2} \mathrm{O}$ 


$$
\begin{aligned}
& \mathrm{MVK}+\mathrm{OH} \longrightarrow 0.72 \times \mathrm{PA}+\mathrm{CH}_{2}(\mathrm{OH}) \mathrm{CHO} \\
& \mathrm{PAN} \longleftrightarrow \mathrm{PA}+\mathrm{NO}_{2} \\
& \mathrm{CH}_{3} \mathrm{C}(\mathrm{O}) \mathrm{CHO}+\mathrm{h} v \longrightarrow \mathrm{PA}+\mathrm{HCO} \\
& \mathrm{CH}_{3} \mathrm{C}(\mathrm{O}) \mathrm{CHO}+\mathrm{OH} \longrightarrow \mathrm{H}_{2} \mathrm{O}+0.6(\mathrm{PA}+\mathrm{CO}) \\
& \quad+0.4\left(\mathrm{CH}_{3}+2 \mathrm{CO}\right) \\
& \mathrm{MACO}_{3}+\mathrm{NO} \longrightarrow 0.35 \mathrm{PA}+\text { products }
\end{aligned}
$$

Biacetyl $+\mathrm{hv} \stackrel{\mathrm{O}_{2}}{\longrightarrow} 2 \mathrm{PA}$

$\mathrm{PA}+\mathrm{NO} \longrightarrow \mathrm{CH}_{3} \mathrm{CO}_{2}+\mathrm{NO}_{2}$

$\mathrm{PA}+\mathrm{HO}_{2} \longrightarrow$ products

$\mathrm{PA}+\mathrm{RO}_{2} \longrightarrow \mathrm{RO}+\mathrm{O}_{2}+\mathrm{CH}_{3} \mathrm{CO}_{2}$

$j_{9}$ was estimated from Eq. (A4) using TUV model as described previously, and $j_{12}$ was scaled with $j_{\mathrm{NO}_{2}}$ (3.64\%) (Klotz et al., 2001). Finally, $\mathrm{CH}_{3} \mathrm{C}(\mathrm{O}) \mathrm{O}$ formed from PA radicals rapidly reacts with $\mathrm{O}_{2}$ to produce $\mathrm{CH}_{3} \mathrm{O}_{2}$ radical.

$$
[\mathrm{PA}]_{\mathrm{ss}}=\frac{\left(\begin{array}{l}
k_{6}\left[\mathrm{CH}_{3} \mathrm{CHO}\right][\mathrm{OH}]+0.72 k_{7}[\mathrm{MVK}][\mathrm{OH}]+ \\
k_{8}[\mathrm{PAN}]+\left(j_{9}+0.6 k_{10}[\mathrm{OH}]\right)[\mathrm{MeGly}]+ \\
0.35 k_{11}[\mathrm{MACO} 3][\mathrm{NO}]+j_{12}[\text { biacetyl }]
\end{array}\right)}{k_{-8}\left[\mathrm{NO}_{2}\right]+k_{13}[\mathrm{NO}]+k_{14}\left[\mathrm{HO}_{2}\right]+k_{15}\left[\mathrm{RO}_{2}\right]}
$$

Once $\mathrm{CH}_{3} \mathrm{O}_{2}$ is formed from the oxidation of $\mathrm{CH}_{4}$ and PA radical, it further reacts with $\mathrm{NO}$ to produce $\mathrm{CH}_{3} \mathrm{O}$ radical and subsequently to generate HCHO. Methyl hydrogen peroxide (MHP, $\mathrm{CH}_{3} \mathrm{OOH}$ ), the product of $\mathrm{CH}_{3} \mathrm{O}_{2}+\mathrm{HO}_{2}$ reactions, also produces $\mathrm{HCHO}$ in all pathways (Fried et al., 1997). Moreover, the $\mathrm{CH}_{3} \mathrm{O}_{2}-\mathrm{CH}_{3} \mathrm{O}_{2}$ self-reaction generates $\mathrm{HCHO}$ as its final product in all pathways (Atkinson et al., 2006; Lightfoot et al., 1991; Tyndall et al., 2001). Therefore, we assumed that once $\mathrm{CH}_{3} \mathrm{O}_{2}$ is generated, it rapidly produces $\mathrm{HCHO}$ with a yield of $100 \%$. Consequently, the $\mathrm{HCHO}$ production rate from $\mathrm{CH}_{3} \mathrm{O}_{2}$ can be estimated by Eq. (C4).

$$
\begin{aligned}
P_{\mathrm{CH} 3 \mathrm{O} 2} & =k_{\mathrm{CH} 4-\mathrm{OH}}\left[\mathrm{CH}_{4}\right][\mathrm{OH}]+\left(k_{13}[\mathrm{NO}]+k_{15}\left[\mathrm{RO}_{2}\right]\right. \\
& \left.+0.4 \times k_{14}\left[\mathrm{HO}_{2}\right]\right) \times[\mathrm{PA}]_{\mathrm{ss}}
\end{aligned}
$$

Recent studies proposed that a new channel of $\mathrm{PA}+\mathrm{HO}_{2}$ reaction can be important with a branching ratio of 0.4 (Dillon and Crowley, 2008; Hasson et al., 2004; Jenkin et al., 2007), through which $\mathrm{CH}_{3} \mathrm{O}_{2}$ is produced, and therefore this new finding can be a potential $\mathrm{HCHO}$ source. We added the new $\mathrm{HCHO}$ producing channel of $\mathrm{PA}+\mathrm{HO}_{2}$ reaction in the $\mathrm{HCHO}$ production calculation (Eq. C4); however, its inclusion resulted in just a 5\% increase in the total $P_{\mathrm{CH}_{3} \mathrm{O}_{2}}$, due to the relatively small impact of $\mathrm{HO}_{2}$ compared to $\mathrm{NO}$ at Blodgett.
Acknowledgements. The lead author would like to thank the Kearney Foundation of Soil Science, the NASA-UCSC University Affiliated Research Center (grant \#NAS2-03144), and the Atmospheric Aerosols \& Health Lead Campus program of the Toxic Substances Research \& Teaching Program for support. The deployment was also supported by a NSF small grant for exploratory research (grant \#0741375). We also thank James Podolske of NASA Ames Research Center for loan of the formaldehyde QCL system, Sierra Pacific Industries for the use of land, Blodgett Forest Research Station staff for cooperation during BEARPEX, and J. A. de Gouw and J. B. Gilman of NOAA for sharing biogenic VOC data. G. Wolfe acknowledges support from NASA Earth Systems Science Fellowship NNG-05GP64H. Discussions with Frank Kuetsch and Jessie Charrier were helpful to the final realization of this work.

Edited by: A. B. Guenther

\section{References}

Alvarado, A., Tuazon, E. C., Aschmann, S. M., Arey, J., and Atkinson, R.: Products and mechanisms of the gas-phase reactions of $\mathrm{OH}$ radicals and O-3 with 2-methyl-3-buten-2-ol, Atmos. Environ., 33, 2893-2905, 1999.

Atkinson, R.: Gas-phase tropospheric chemistry of volatile organic compounds 1. Alkanes and alkenes, J. Phys. Chem. Ref. Data, 26, 215-290, 1997.

Atkinson, R., Baulch, D. L., Cox, R. A., Hampson, R. F., Kerr, J. A., Rossi, M. J., and Troe, J.: Evaluated kinetic and photochemical data for atmospheric chemistry, organic species: Supplement VII, J. Phys. Chem. Ref. Data, 28, 191-393, 1999.

Atkinson, R. and Arey, J.: Gas-phase tropospheric chemistry of biogenic volatile organic compounds: a review, Atmos. Environ., 37, S197-S219, doi:10.1016/s1352-2310(03)00391-1, 2003.

Atkinson, R., Baulch, D. L., Cox, R. A., Crowley, J. N., Hampson, R. F., Hynes, R. G., Jenkin, M. E., Rossi, M. J., and Troe, J.: Evaluated kinetic and photochemical data for atmospheric chemistry: Volume $\mathrm{I}$ - gas phase reactions of $\mathrm{O}_{\mathrm{x}}, \mathrm{HO}_{\mathrm{x}}, \mathrm{NO}_{\mathrm{x}}$ and $\mathrm{SO}_{\mathrm{X}}$ species, Atmos. Chem. Phys., 4, 1461-1738, doi:10.5194/acp-41461-2004, 2004.

Atkinson, R., Baulch, D. L., Cox, R. A., Crowley, J. N., Hampson, R. F., Hynes, R. G., Jenkin, M. E., Rossi, M. J., Troe, J., and IUPAC Subcommittee: Evaluated kinetic and photochemical data for atmospheric chemistry: Volume II - gas phase reactions of organic species, Atmos. Chem. Phys., 6, 3625-4055, doi:10.5194/acp-6-3625-2006, 2006.

Bacher, C., Tyndall, G. S., and Orlando, J. J.: The atmospheric chemistry of glycolaldehyde, J. Atmos. Chem., 39, 171-189, 2001.

Baeza-Romero, M. T., Glowacki, D. R., Blitz, M. A., Heard, D. E., Pilling, M. J., Rickard, A. R., and Seakins, P. W.: A combined experimental and theoretical study of the reaction between methylglyoxal and OH/OD radical: OH regeneration, Phys. Chem. Chem. Phys., 9, 4114-4128, 2007.

Bouvier-Brown, N. C., Goldstein, A. H., Gilman, J. B., Kuster, W. C., and de Gouw, J. A.: In-situ ambient quantification of monoterpenes, sesquiterpenes, and related oxygenated compounds during BEARPEX 2007: implications for gas- and 
particle-phase chemistry, Atmos. Chem. Phys., 9, 5505-5518, doi:10.5194/acp-9-5505-2009, 2009a.

Bouvier-Brown, N. C., Holzinger, R., Palitzsch, K., and Goldstein, A. H.: Large emissions of sesquiterpenes and methyl chavicol quantified from branch enclosure measurements, Atmos. Environ., 43, 389-401, doi:10.1016/j.atmosenv.2008.08.039, 2009b.

Bowman, F. M., Pilinis, C., and Seinfeld, J. H.: Ozone and aerosol productivity of reactive organics, Atmos. Environ., 29, 579-589, 1995.

Butkovskaya, N. I., Pouvesle, N., Kukui, A., and Le Bra, G.: Mechanism of the $\mathrm{OH}$-initiated oxidation of glycolaldehyde over the temperature range 233-296 K, J. Phys. Chem., 110, 1349213499, 2006.

Calogirou, A., Kotzias, D., and Kettrup, A.: Product analysis of the gas-phase reaction of beta-caryophyllene with ozone, Atmos. Environ., 31, 283-285, 1997.

Choi, W., Faloona, I. C., McKay, M., Goldstein, A. H., and Baker, B.: Estimating the atmospheric boundary layer height over sloped, forested terrain from surface spectral analysis during BEARPEX, Atmos. Chem. Phys. Discuss., in review, 2010.

Day, D. A., Farmer, D. K., Goldstein, A. H., Wooldridge, P. J., Minejima, C., and Cohen, R. C.: Observations of $\mathrm{NO}_{\mathrm{x}}, \Sigma \mathrm{PNs}$, $\Sigma \mathrm{ANs}$, and $\mathrm{HNO}_{3}$ at a Rural Site in the California Sierra Nevada Mountains: summertime diurnal cycles, Atmos. Chem. Phys., 9, 4879-4896, doi:10.5194/acp-9-4879-2009, 2009.

Dillon, T. J. and Crowley, J. N.: Direct detection of OH formation in the reactions of $\mathrm{HO}_{2}$ with $\mathrm{CH}_{3} \mathrm{C}(\mathrm{O}) \mathrm{O}_{2}$ and other substituted peroxy radicals, Atmos. Chem. Phys., 8, 4877-4889, doi:10.5194/acp-8-4877-2008, 2008.

Dillon, M. B., Lamanna, M. S., Schade, G. W., Goldstein, A. H., and Cohen, R. C.: Chemical evolution of the Sacramento urban plume: Transport and oxidation, J. Geophys. Res.-Atmos., 107, 4045, doi:10.1029/2001jd000969, 2002.

Dreyfus, G. B., Schade, G. W., and Goldstein, A. H.: Observational constraints on the contribution of isoprene oxidation to ozone production on the western slope of the Sierra Nevada, California, J. Geophys. Res.-Atmos., 107, 4365, doi:10.1029/2001jd001490, 2002.

Facchini, M. C., Fuzzi, S., Lind, J. A., Fierlingeroberlinninger, H., Kalina, M., Puxbaum, H., Winiwarter, W., Arends, B. G., Wobrock, W., Jaeschke, W., Berner, A., and Kruisz, C.: Phasepartitioning and chemical-reactions of low-molecular-weight organic-compounds in fog, Tellus B, 44, 533-544, 1992.

Faloona, I., Tan, D., Brune, W., Hurst, J., Barket, D., Couch, T. L., Shepson, P., Apel, E., Riemer, D., Thornberry, T., Carroll, M. A., Sillman, S., Keeler, G. J., Sagady, J., Hooper, D., and Paterson, K.: Nighttime observations of anomalously high levels of hydroxyl radicals above a deciduous forest canopy, J. Geophys. Res.-Atmos., 106, 24315-24333, 2001.

Fantechi, G., Jensen, N. R., Hjorth, J., and Peeters, J.: Mechanistic studies of the atmospheric oxidation of methyl butenol by $\mathrm{OH}$ radicals, ozone and $\mathrm{NO}_{3}$ radicals, Atmos. Environ., 32, 35473556, 1998.

Farmer, D. K. and Cohen, R. C.: Observations of $\mathrm{HNO}_{3}, \Sigma \mathrm{AN}$, $\Sigma \mathrm{PN}$ and $\mathrm{NO}_{2}$ fluxes: evidence for rapid $\mathrm{HO}_{\mathrm{x}}$ chemistry within a pine forest canopy, Atmos. Chem. Phys., 8, 3899-3917, doi:10.5194/acp-8-3899-2008, 2008.

Ferronato, C., Orlando, J. J., and Tyndall, G. S.: Rate and mechanism of the reactions of $\mathrm{OH}$ and $\mathrm{Cl}$ with 2-methyl-3-buten-2-ol,
J. Geophys. Res., 103, D19, 25579-25586, 1998.

Fried, A., McKeen, S., Sewell, S., Harder, J., Henry, B., Goldan, P., Kuster, W., Williams, E., Baumann, K., Shetter, R., and Cantrell, C.: Photochemistry of formaldehyde during the 1993 Tropospheric OH Photochemistry Experiment, J. Geophys. Res.Atmos., 102, 6283-6296, 1997.

Goldstein, A. H., Hultman, N. E., Fracheboud, J. M., Bauer, M. R., Panek, J. A., Xu, M., Qi, Y., Guenther, A. B., and Baugh, W.: Effects of climate variability on the carbon dioxide, water, and sensible heat fluxes above a ponderosa pine plantation in the Sierra Nevada (CA), Agric. For. Meteorol., 101, 113-129, 2000.

Gratien, A., Picquet-Varrault, B., Orphal, J., Perraudin, E., Doussin, J. F., and Flaud, J. M.: Laboratory intercomparison of the formaldehyde absorption cross sections in the infrared $(1660-1820 \mathrm{~cm}(-1))$ and ultraviolet $(300-360 \mathrm{~nm})$ spectral regions, J. Geophys. Res.-Atmos., 112, D05305, doi:10.1029/2006jd007201, 2007.

Griffin, R. J., Cocker, D. R., and Seinfeld, J. H.: Incremental aerosol reactivity: application to aromatic and biogenic hydrocarbons, Environ. Sci. Technol., 33, 2403-2408, 1999.

Grosjean, D.: Formaldehyde and other carbonyls in Los-Angeles ambient air, Environ. Sci. Technol., 16, 254-262, 1982.

Grosjean, D., Miguel, A. H., and Tavares, T. M.: Urban airpollution in Brazil - acetaldehyde and other carbonyls, Atmos. Environ., 24, 101-106, 1990.

Grosjean, D., Williams, E. L., and Grosjean, E.: Atmospheric chemistry of isoprene and of its carbonyl products, Environ. Sci. Technol., 27, 830-840, 1993a.

Grosjean, D., Williams, E. L., Grosjean, E., Andino, J. M., and Seinfeld, J. H.: Atmospheric oxidation of biogenic hydrocarbons - reaction of ozone with beta-pinene, d-limonene and transcaryophyllene, Environ. Sci. Technol., 27, 2754-2758, 1993 b.

Grosjean, D. and Grosjean, E.: Carbonyl products of the ozoneunsaturated alcohol reaction, J. Geophys. Res., 100, D11, 2281522820, 1995.

Hasson, A. S., Tyndall, G. S., and Orlando, J. J.: A product yield study of the reaction of $\mathrm{HO}_{2}$ radicals with ethyl peroxy (C2H5O2), acetyl peroxy $(\mathrm{CH} 3 \mathrm{C}(\mathrm{O}) \mathrm{O}-2)$, and acetonyl peroxy (CH3C(O)CH2O2) radicals, J. Phys. Chem. A, 108, 5979-5989, doi:10.1021/jp048873t, 2004.

Hauglustaine, D. A. and Ehhalt, D. H.: A three-dimensional model of molecular hydrogen in the troposphere, J. Geophys. Res.Atmos., 107, 4330, doi:10.1029/2001jd001156, 2002.

Hermans, I., Muller, J. F., Nguyen, T. L., Jacobs, P. A., and Peeters, J.: Kinetics of alpha-hydroxy-alkylperoxyl radicals in oxidation processes. $\mathrm{HO}_{2}$ center dot-initiated oxidation of ketones/aldehydes near the tropopause, J. Phys. Chem. A, 109, 4303-4311, doi:10.1021/jp044080v, 2005.

Hobbs, P. C. D.: Ultrasensitive laser measurements without tears, Appl. Opt., 36, 903-920, 1997.

Hoffmann, T., Odum, J. R., Bowman, F., Collins, D., Klockow, D., Flagan, R. C., and Seinfeld, J. H.: Formation of organic aerosols from the oxidation of biogenic hydrocarbons, J. Atmos. Chem., 26, 189-222, 1997.

Hofzumahaus, A., Rohrer, F., Lu, K. D., Bohn, B., Brauers, T., Chang, C. C., Fuchs, H., Holland, F., Kita, K., Kondo, Y., Li, X., Lou, S. R., Shao, M., Zeng, L. M., Wahner, A., and Zhang, Y. H.: Amplified Trace Gas Removal in the Troposphere, Science, 324, 1702-1704, doi:10.1126/science.1164566, 2009. 
Holzinger, R., Lee, A., Paw, K. T., and Goldstein, U. A. H.: Observations of oxidation products above a forest imply biogenic emissions of very reactive compounds, Atmos. Chem. Phys., 5, 67-75, doi:10.5194/acp-5-67-2005, 2005.

Hurst, J. M., Barket, D. J., Herrera-Gomez, O., Couch, T. L., Shepson, P. B., Faloona, I., Tan, D., Brune, W., Westberg, H., Lamb, B., Biesenthal, T., Young, V., Goldstein, A., Munger, J. W., Thornberry, T., and Carroll, M. A.: Investigation of the nighttime decay of isoprene, J. Geophys. Res.-Atmos., 106, 24335-24346, 2001.

IPCC: Climate Change 2007: The Physical Science Basis, Intergovernmental Panel on Climate Change, Chapter 2, 140-143, 2007.

Jenkin, M. E., Boyd, A. A., and Lesclaux, R.: Peroxy radical kinetics resulting from the $\mathrm{OH}$-Initiated oxidation of 1,3-butadiene, 2,3-dimethyl-1,3-butadiene and isoprene, J. Atmos. Chem., 29, 267-298, 1998.

Jenkin, M. E., Hurley, M. D., and Wallington, T. J.: Investigation of the radical product channel of the $\mathrm{CH}_{3} \mathrm{C}(\mathrm{O}) \mathrm{O}-2+\mathrm{HO}_{2}$ reaction in the gas phase, Phys. Chem. Chem. Phys., 9, 3149-3162, doi:10.1039/b702757e, 2007.

Kamat, P. C., Roller, C. B., Namjou, K., Jeffers, J. D., Faramarzalian, A., Salas, R., and McCann, P. J.: Measurement of acetaldehyde in exhaled breath using a laser absorption spectrometer, Appl. Opt., 46(19), 3969-3975, 2007.

Karl, M., Dorn, H.-P., Holland, F., Koppmann, R., Poppe, D., Rupp, L., Schaub, A., and Wahner, A.: Product study of the reaction of $\mathrm{OH}$ radicals with isoprene in the atmosphere simulation chamber SAPHIR, J. Atmos. Chem., 55, 167-187, 2006.

Kegley-Owen, C. S., Tyndall, G. S., Orlando, J. J., and Fried, A.: Tunable diode laser studies of the reaction of $\mathrm{Cl}$ atoms with $\mathrm{CH}_{3} \mathrm{CHO}$, Int. J. Chem. Kinet., 31, 766-775, 1999.

Klotz, B., Graedler, F., Sorensen, S., Barnes, I., and Becker, K. H.: A kinetic study of the atmospheric photolysis of alphadicarbonyls, Int. J. Chem. Kinet., 33, 9-20, 2001.

Koch, G. and Moortgat, G. K.: Photochemistry of methylglyoxal in the vapor phase, J. Phys. Chem. A, 102, 9142-9153, 1998.

Krinke, S. M. and Wahner, A.: Formaldehyde and ozone deposition velocities determined above a deciduous forest during summer, Eos Trans AGU, 80(46), Fall Meet. Suppl., F158, 1999.

Kurpius, M. R. and Goldstein, A. H.: Gas-phase chemistry dominates O-3 loss to a forest, implying a source of aerosols and hydroxyl radicals to the atmosphere, Geophys. Res. Lett., 30, 1371, doi:10.1029/2002g1016785, 2003.

LaFranchi, B. W., Wolfe, G. M., Thornton, J. A., Harrold, S. A., Browne, E. C., Min, K. E., Wooldridge, P. J., Gilman, J. B., Kuster, W. C., Goldan, P. D., de Gouw, J. A., McKay, M., Goldstein, A. H., Ren, X., Mao, J., and Cohen, R. C.: Closing the peroxy acetyl nitrate budget: observations of acyl peroxy nitrates (PAN, PPN, and MPAN) during BEARPEX 2007, Atmos. Chem. Phys., 9, 7623-7641, doi:10.5194/acp-9-7623-2009, 2009.

Largiuni, O., Giacomelli, M. C., and Piccardi, G.: Concentration of peroxides and formaldehyde in air and rain and gas-rain partitioning, J. Atmos. Chem., 41, 1-20, 2002.

Lee, A., Goldstein, A. H., Keywood, M. D., Gao, S., Varutbangkul, V., Bahreini, R., Ng, N. L., Flagan, R. C., and Seinfeld, J. H.: Gas-phase products and secondary aerosol yields from the ozonolysis of ten different terpenes, J. Geophys. Res.-Atmos., 111, D07302, doi:10.1029/2005jd006437, 2006a.

Lee, A., Goldstein, A. H., Kroll, J. H., Ng, N. L., Varut- bangkul, V., Flagan, R. C., and Seinfeld, J. H.: Gas-phase products and secondary aerosol yields from the photooxidation of 16 different terpenes, J. Geophys. Res.-Atmos., 111, D17305, doi:10.1029/2006jd007050, 2006b.

Lee, Y. N., Zhou, X., Kleinman, L. I., Nunnermacker, L. J., Springston, S. R., Daum, P. H., Newman, L., Keigley, W. G., Holdren, M. W., Spicer, C. W., Young, V., Fu, B., Parrish, D. D., Holloway, J., Williams, J., Roberts, J. M., Ryerson, T. B., and Fehsenfeld, F. C.: Atmospheric chemistry and distribution of formaldehyde and several multioxygenated carbonyl compounds during the 1995 Nashville Middle Tennessee Ozone Study, J. Geophys. Res.-Atmos., 103, 22449-22462, 1998.

Lelieveld, J., Butler, T. M., Crowley, J. N., Dillon, T. J., Fischer, H., Ganzeveld, L., Harder, H., Lawrence, M. G., Martinez, M., Taraborrelli, D., and Williams, J.: Atmospheric oxidation capacity sustained by a tropical forest, Nature, 452, 737-740, doi:10.1038/nature06870, 2008.

Lightfoot, P. D., Roussel, P., Caralp, F., and Lesclaux, R.: Flashphotolysis study of the $\mathrm{CH}_{3} \mathrm{O}_{2}+\mathrm{CH}_{3} \mathrm{O}_{2}$ and $\mathrm{CH}_{3} \mathrm{O}_{2}+\mathrm{HO}_{2}$ reactions between $60-\mathrm{K}$ and $719-\mathrm{K}$ - unimolecular decomposition of methylhydroperoxide, J. Chem. Soc. Faraday Trans., 87, 3213-3220, 1991.

Macdonald, A. M., Makar, P. A., Anlauf, K. G., Hayden, K. L., Bottenheim, J. W., Wang, D., and Dann, T.: Summertime formaldehyde at a high-elevation site in Quebec, J. Geophys. Res.-Atmos., 106, 32361-32374, 2001.

Macoas, E. M. S., Lundell, J., Pettersson, M., Khriachtchev, L., Fausto, R., and Rasanen, M.: Vibrational spectroscopy of cisand trans-formic acid in solid argon, J. Mol. Spectrosc., 219, 7080, doi:10.1016/s0022-2852(03)00018-3, 2003.

Magneron, I., Mellouki, A., Le Bras, G., Moortgat, G. K., Horowitz, A., and Wirtz, K.: Photolysis and OH-Initiated oxidation of glycolaldehyde under atmospheric conditions, J. Phys. Chem. A, 109, 4552-4561, doi:10.1021/jp044346y, 2005.

Mao, J., Ren, X., Chen, Z., Brune, W., LaFranchi, B., Cohen, R., Gilman, J., and De Gouw, J.: HO chemistry in and above a forest canopy in seasonal transition, AGU Fall Meeting, A32C-03, Oral Presentation, San Francisco, USA, 2008.

Martin, R. V., Parrish, D. D., Ryerson, T. B., Nicks, D. K., Chance, K., Kurosu, T. P., Jacob, D. J., Sturges, E. D., Fried, A., and Wert, B. P.: Evaluation of GOME satellite measurements of tropospheric $\mathrm{NO}_{2}$ and $\mathrm{HCHO}$ using regional data from aircraft campaigns in the southeastern United States, J. Geophys. Res.Atmos., 109, D24307, doi:10.1029/2004jd004869, 2004.

Millet, D. B., Jacob, D. J., Boersma, K. F., Fu, T. M., Kurosu, T. P., Chance, K., Heald, C. L., and Guenther, A.: Spatial distribution of isoprene emissions from North America derived from formaldehyde column measurements by the OMI satellite sensor, J. Geophys. Res.-Atmos., 113, D02307, doi:10.1029/2007jd008950, 2008.

Misson, L., Tang, J. W., Xu, M., McKay, M., and Goldstein, A.: Influences of recovery from clear-cut, climate variability, and thinning on the carbon balance of a young ponderosa pine plantation, Agric. For. Meteorol., 130, 207-222, doi:10.1016/j.agrformet.2005.04.001, 2005.

Miyoshi, A., Hatakeyama, S., and Washida, N.: OH radicalinitiated photooxidation of isoprene - an estimate of global CO production, J. Geophys. Res.-Atmos., 99, 18779-18787, 1994.

Moise, T., Denzer, W., and Rudich, Y.: Direct kinetics study of 
the reaction of peroxyacetyl radical with NO between 218 and 370 K, J. Phys. Chem. A, 103, 6766-6771, 1999.

Monson, R. K. and Fall, R.: Isoprene emission from Aspen leaves - influence of environment and relation to photosynthesis and photorespiration, J. Plant Physiol., 90, 267-274, 1989.

Muller, K., Pelzing, M., Gnauk, T., Kappe, A., Teichmann, U., Spindler, G., Haferkorn, S., Jahn, Y., and Herrmann, H.: Monoterpene emissions and carbonyl compound air concentrations during the blooming period of rape (Brassica napus), Chemosphere, 49, 1247-1256, 2002.

Munger, J. W., Jacob, D. J., and Hoffmann, M. R.: The occurrence of bisulfite-aldehyde addition-products in fogwater and cloudwater, J. Atmos. Chem., 1, 335-350, 1984.

Murphy, J. G., Day, D. A., Cleary, P. A., Wooldridge, P. J., Millet, D. B., Goldstein, A. H., and Cohen, R. C.: The weekend effect within and downwind of Sacramento - Part 1: Observations of ozone, nitrogen oxides, and VOC reactivity, Atmos. Chem. Phys., 7, 5327-5339, doi:10.5194/acp-7-5327-2007, 2007.

National Center for Atmospheric Research (NCAR): TUV Radiation Model v4.5, online: http://cprm.acd.ucar.edu/Models/TUV/, 2008.

Orlando, J. J., Tyndall, G. S., and Paulson, S. E.: Mechanism of the $\mathrm{OH}$-initiated oxidation of methacrolein, Geophys. Res. Lett., 26, 2191-2194, 1999.

Paulot, F., Crounse, J. D., Kjaergaard, H. G., Kroll, J. H., Seinfeld, J. H., and Wennberg, P. O.: Isoprene photooxidation: new insights into the production of acids and organic nitrates, Atmos. Chem. Phys., 9, 1479-1501, doi:10.5194/acp-9-1479-2009, 2009.

Paulson, S. E., Flagan, R. C., and Seinfeld, J. H.: Atmospheric photooxidation of isoprene, 1 . The hydroxyl radical and ground-state atomic oxygen reactions, Int. J. Chem. Kinet., 24, 79-101, 1992.

Perrin, A., Keller, F., and Flaud, J. M.: New analysis of the $\mathrm{nu}(2), \mathrm{nu}(3), \mathrm{nu}(4)$, and nu(6) bands of formaldehyde, $\left(\mathrm{H}_{2} \mathrm{CO}\right)-$ $\mathrm{C}-12-\mathrm{O}-16$ line positions and intensities in the $5-10 \mu \mathrm{m}$ spectral region, J. Mol. Spectrosc., 221, 192-198, doi:10.1016/s00222852(03)00207-8, 2003.

Possanzini, M., Dipalo, V., Petricca, M., Fratarcangeli, R., and Brocco, D.: Measurements of lower carbonyls in Rome ambient air, Atmos. Environ., 30, 3757-3764, 1996.

Ruppert, L. and Becker, K. H.: A product study of the $\mathrm{OH}$ radicalinitiated oxidation of isoprene: formation of C-5-unsaturated diols, Atmos. Environ., 34, 1529-1542, 2000.

Seinfeld, J. H. and Pandis, S. N.: Atmospheric Chemistry and Physics: from Air Pollution to Climate Change, John Willey \& Sons, Inc, 1998.

Shepson, P. B., Bottenheim, J. W., Hastie, D. R., and Venkatram, A.: Determination of the relative ozone and PAN deposition velocities at night, Geophys. Res. Lett., 19, 1121-1124, 1992.

Spaulding, R. S., Schade, G. W., Goldstein, A. H., and Charles, M. J.: Characterization of secondary atmospheric photooxidation products: Evidence for biogenic and anthropogenic sources, J. Geophys. Res.-Atmos., 108, 4247, doi:10.1029/2002jd002478, 2003.

Sprengnether, M., Demerjian, K. L., Donahue, N. M., and Anerson, J. G.: Product analysis of the $\mathrm{OH}$ oxidation of isoprene and 1,3butadiene in the presence of NO, J. Geophys. Res., 107, 4269, doi:10.1029/2001JD000716, 2002.
Steiner, A. L., Tonse, S., Cohen, R. C., Goldstein, A. H., and Harley, R. A.: Biogenic 2-methyl-3-buten-2-ol increases regional ozone and $\mathrm{HO}_{\mathrm{x}}$ sources, Geophys. Res. Lett., 34, L15806, doi:10.1029/2007g1030802, 2007.

Stevens, P., L'Esperance, D., Chuong, B., and Martin, G.: Measurements of the kinetics of the $\mathrm{OH}$-initiated oxidation of isoprene: Radical propagation in the $\mathrm{OH}+$ isoprene $+\mathrm{O}-2+\mathrm{NO}$ reaction system, Int. J. Chem. Kinet., 31, 637-643, 1999.

Stevens, P. S., Mather, J. H., Brune, W. H., Eisele, F., Tanner, D., Jefferson, A., Cantrell, C., Shetter, R., Sewall, S., Fried, A., Henry, B., Williams, E., Baumann, K., Goldan, P., and Kuster, W.: $\mathrm{HO}_{2} / \mathrm{OH}$ and $\mathrm{RO}(2) / \mathrm{HO}_{2}$ ratios during the Tropospheric $\mathrm{OH}$ Photochemistry Experiment: Measurement and theory, J. Geophys. Res.-Atmos., 102, 6379-6391, 1997.

Suh, H. H., Bahadori, T., Vallarino, J., and Spengler, J. D.: Criteria air pollutants and toxic air pollutants, Environ. Health Perspect., 108, 625-633, 2000.

Sumner, A. L., Shepson, P. B., Couch, T. L., Thornberry, T., Carroll, M. A., Sillman, S., Pippin, M., Bertman, S., Tan, D., Faloona, I., Brune, W., Young, V., Cooper, O., Moody, J., and Stockwell, W.: A study of formaldehyde chemistry above a forest canopy, J. Geophys. Res.-Atmos., 106, 24387-24405, 2001.

Tan, D., Faloona, I., Simpas, J. B., Brune, W., Shepson, P. B., Couch, T. L., Sumner, A. L., Carroll, M. A., Thornberry, T., Apel, E., Riemer, D., and Stockwell, W.: $\mathrm{HO}_{\mathrm{x}}$ budgets in a deciduous forest: results from the PROPHET summer 1998 campaign, J. Geophys. Res.-Atmos., 106, 24407-24427, 2001.

Thornton, J. A., Wooldridge, P. J., Cohen, R. C., Martinez, M., Harder, H., Brune, W. H., Williams, E. J., Roberts, J. M., Fehsenfeld, F. C., Hall, S. R., Shetter, R. E., Wert, B. P., and Fried, A.: Ozone production rates as a function of $\mathrm{NO}_{\mathrm{x}}$ abundances and $\mathrm{HO}_{\mathrm{x}}$ production rates in the Nashville urban plume, J. Geophys Res.-Atmos., 107, 4146, doi:10.1029/2001jd000932, 2002.

Tuazon, E. C. and Atkinson, R.: A product study of the gas-phase reaction of isoprene with the $\mathrm{OH}$ radical in the presence of $\mathrm{NO}$, Int. J. Chem. Kinet., 22, 1221-1236, 1990.

Tyndall, G. S., Cox, R. A., Granier, C., Lesclaux, R., Moortgat, G. K., Pilling, M. J., Ravishankara, A. R., and Wallington, T. J.: Atmospheric chemistry of small organic peroxy radicals, J. Geophys. Res.-Atmos., 106, 12157-12182, 2001.

Wolfe, G. M., Thornton, J. A., Bouvier-Brown, N. C., Goldstein, A. H., Park, J.-H., McKay, M., Matross, D. M., Mao, J., Brune, W. H., LaFranchi, B. W., Browne, E. C., Min, K.-E., Wooldridge, P. J., Cohen, R. C., Crounse, J. D., Faloona, I. C., Gilman, J. B., Kuster, W. C., de Gouw, J. A., Huisman, A., and Keutsch, F. N.: The chemistry of Atmosphere-Forest Exchange (CAFE) Model - Part 2: Application to BEARPEX-2007 observations, Atmos. Chem. Phys. Discuss., in press, 2010.

Wolfe, G. M., Thornton, J. A., Yatavelli, R. L. N., McKay, M., Goldstein, A. H., LaFranchi, B., Min, K.-E., and Cohen, R. C.: Eddy covariance fluxes of acyl peroxy nitrates (PAN, PPN and MPAN) above a Ponderosa pine forest, Atmos. Chem. Phys., 9, 615-634, doi:10.5194/acp-9-615-2009, 2009. 